GARCÍA PALOMINOS, Gonzalo. "Modelo de protección en normas administrativas y penales que regulan el abuso de Información Privilegiada en la legislación chilena".

Polít. crim. Vol. 8, No 15 (Julio 2013), Art. 2, pp. 23 - 63.

[http://www.politicacriminal.cl/Vol_08/n_15/Vol8N15A2.pdf]

\title{
Modelo de protección en normas administrativas y penales que regulan el abuso de Información Privilegiada en la legislación chilena.
}

\author{
Dr. Gonzalo García Palominos, L.L. M (Freiburg i.B)* \\ Académico del Departamento de Derecho Penal \\ Universidad Alberto Hurtado \\ ggarcia@uahurtado.cl
}

\section{Resumen}

El objetivo del presente artículo es abordar la problemática de la falta de claridad en la literatura nacional relativa al modelo de protección y la estructura normativa del abuso de información privilegiada en el ordenamiento jurídico chileno. Luego de una exposición introductoria de los modelos de protección desarrollados por la literatura internacional y después de describir sus manifestaciones y conflictos en la literatura chilena, se propone un análisis histórico y sistemático de los elementos que configuran la prohibición y la sanción de dichas conductas, de lo que surgen los resultados de la investigación: la normativa chilena responde al modelo de protección institucional del mercado de valores.

\section{Palabras clave}

Uso de información privilegiada, insider, mercado de valores, derecho penal, derecho administrativo sancionador, Ley $\mathrm{N}^{\circ} 18.045$.

\begin{abstract}
The purpose of this article is to analyze the lack of clarity in national literature concerning the standard of protection and normative structure of insider trading in the Chilean legal system. After an initial review of the standards of protection established by international literature, followed by a description of its manifestations and conflicts in domestic literature, we propose an historical systematical analysis of the elements that constitute the prohibition and punishment of such conducts, from which the results of this research arise: The Chilean legal system shows its adherence to the institutionalized standard of protection of the stock market.
\end{abstract}

\section{Key words}

Insider trading, insider, stock market, criminal law, sanctioning administrative law, Law $\mathrm{N}^{\circ}$ 18.045 . 
GARCÍA PALOMINOS, Gonzalo. "Modelo de protección en normas administrativas y penales que regulan el abuso de Información Privilegiada en la legislación chilena".

\section{Introducción}

a) El abuso de información privilegiada se encuentra sancionado en Chile administrativa y penalmente tanto en la Ley de Mercado de Valores $\mathrm{N}^{\circ} 18.045$ de 1981 (Art. 165, 60 e), g) y h)) como en el Decreto Ley 3.500 de 1980 sobre Sistema de Pensiones (Art. 159). ${ }^{1}$ Respecto a la fundamentación de las normas de conducta y justificación de las normas de sanción administrativa y penal no existe hoy en día ni una opinión unánime ni clara en la doctrina chilena. Dicha falta de claridad - que se expresa en la discusión sobre la ratio legis, el bien jurídico protegido y su estructura normativa- obedece a fenómenos mucho más complejos que los hasta ahora abordados por la doctrina chilena. ${ }^{2}$

* Dirección postal: Facultad de Derecho Universidad Alberto Hurtado, Cienfuegos 41, Santiago, Chile.

${ }^{1}$ El art. 159 D.L. 3.500 establece dos ilícitos relacionados con el uso y divulgación de "Información Privilegiada" y relativos a cualquier operación o transacción de "valores de oferta pública" -en la letra a) - y "a las decisiones de inversión de cualquiera de los Fondos en "valores de oferta pública"”. Por su parte, el artículo Art. 60 LMV establece cuatro ilícitos penales. Los tres primeros ilícitos - letras e), g) y h) - se refieren a usar o revelar deliberadamente "información privilegiada", cuando se trate de transacciones u operaciones sobre "valores de oferta pública", mientras que el ilícito penal de la letra d) se refiere a la revelación de información reservada en razón de su cargo o posición en las sociedades clasificadoras.

${ }^{2}$ Entre la literatura más representativa se pueden nombrar ALCALDE RODRÍGUEZ, Enrique, "Uso de Información Privilegiada: Algunas consideraciones sobre el sentido y alcance de la prohibición en relación con su sujeto, objeto y sanción", Revista Chilena de Derecho, vol. 27, № 1 (2000), pp. 11 - 28; ONFRAY VIVANCO, Arturo, "Ilícitos contra la información en las transacciones de valores", Revista de Derecho Consejo de Defensa del Estado, № 5 (2001), pp. 73 - 105; PRADO PUGA, Arturo, "Acerca del concepto de Información Privilegiada en el mercado de valores chileno: Su alcance, contenido y límites", Revista Chilena de Derecho, vol. $30 \mathrm{~N}^{\circ} 2$ (2003), pp. 237 - 269; CANALES, Patricia, Información Privilegiada en la Ley del Mercado de Valores, Serie Estudios de Anticipación/CEA, Biblioteca del Congreso Nacional de Chile, Año II $\mathrm{N}^{\circ} 18$, Mayo de 2003; SALAH ABUSLEME, María Agnes, Responsabilidad por uso de Información Privilegiada en el Mercado de Valores, Santiago: Lexis Nexis, 2004; RIED UNDURRAGA, "Fundamentos de la Prohibición del Uso de la Información Privilegiada en Chile: Una visión crítica", Revista Chilena de Derecho, vol. 31, № 3 (2004), pp. 439 - 463; RIED UNDURRAGA, José Miguel, "El caso Consorcio 2 Banco de Chile: Información Privilegiada y potestad sancionadora de la Administración”, en: Sentencias Destacadas 2005 una mirada desde la perspectiva de las políticas públicas, Revista del Instituto Libertad y Desarrollo, Santiago, 2005, pp. 31 - 44; ROSAS, Juan Ignacio, "El Delito de Abuso de Información Privilegiada en el Mercado de Valores: Análisis crítico de la regulación contenida en la Ley $\mathrm{N}^{\circ} 18.045$ ", Revista Gaceta Jurídica, N 299 (2005), pp. 7 - 24; GUZMÁN ANRIQUE, Francisco, Información Privilegiada en el Mercado de Valores, Santiago: Lexis Nexis, 2007; STIPP, Anne Caroline, El Delito de Abuso de Información Privilegiada, Bogotá, Colombia: Editorial Leyer, 2009 (en su último capítulo se refiere al derecho chileno); PIÑA ROCHEFORT, Juan Ignacio, "Algunos problemas del delito de uso de información privilegiada", Cuadernos de Extensión Jurídica, Santiago, tomo 19 (2009), pp. 113 - 135; PFEFFER, Francisco, "Concepto de información privilegiada y deberes de conducta de quienes están en posesión de ella, a la luz de la jurisprudencia emanada de la Excma. Corte Suprema“, Revista de Derecho Comercial, Universidad de Chile, Año 1 No 1 (2010), pp. 155-181; BASCUÑÁN RODRIGUEZ, Antonio, "La regulación de la información privilegiada en el mercado de valores después de la Ley 20.382", en: VVAA, Gobiernos Corporativos. Aspectos especiales de las Reformas a su regulación, Universidad Adolfo Ibáñez, Santiago: Editorial AbeledoPerrot, 2011, pp. 87 - 138; VÁSQUEZ PALMA, María Fernanda, "Revisión del ámbito de aplicación subjetivo y objetivo de la noción de uso de información privilegiada en Chile: un examen de la normativa a la luz de las tendencias doctrinales y jurisprudenciales", Revista de Derecho Universidad Católica del Norte, Año 17 - No 2 (2010), pp. 239-297; GASPAR, José Antonio; ARAYA, Fernando, "Uso de Información Privilegiada: Superintendencia de Valores y Seguros, 14 de abril de 2011, Resolución Exenta No 229”, Revista Chilena de Derecho Privado, No 17 (2011), pp. 277 - 305. 
Polít. crim. Vol. 8, № 15 (Julio 2013), Art. 2, pp. 23 - 63.

[http://www.politicacriminal.cl/Vol_08/n_15/Vol8N15A2.pdf]

La falta de claridad respecto al modelo de protección y sistemática normativa, que redunda en un posible problema de legitimidad de las normas sobre abuso de información privilegiada y en problemas de coherencia en su aplicación, obedece a dos tipos de fenómenos en los discursos jurídicos: un primer fenómeno dice relación con la falta de claridad y coherencia entre el modelo de protección presentado originalmente por el legislador y la sistemática de la actual normativa. Lo anterior se agrava con los importantes niveles de distorsión que genera la integración de argumentos de lege ferenda en la interpretación del sistema por una parte de la literatura. ${ }^{3}$ Mientras que el segundo fenómeno, exclusivamente interno de los discursos penales, se refiere a la tendencia tanto a la administrativización del derecho penal como a la idealización de los ámbitos de protección, en este caso del mercado de valores como objeto de protección penal. Con ello, se confirma el abandono de la literatura penal de la búsqueda de un injusto penal calificado que justifique la imposición de una sanción penal. Objetivo del presente artículo es sólo hacer frente al primer fenómeno -común al derecho privado, al derecho administrativo sancionador y al derecho penal- y contestar a la interrogante sobre cuál es el modelo de protección chileno en las infracciones administrativas y delitos de uso de información privilegiada de la Ley 18.045, según la lógica de su sistemática normativa.

b) Para demostrar la importancia de la problemática, es necesario acentuar su perspectiva sistemática. Con el concepto de abuso de información privilegiada se designan una serie de conductas desvaloradas administrativa y penalmente y que abarcan todo aprovechamiento de cierta información no pública ya sea por medio de su utilización en transacciones en el mercado de valores o a través de la divulgación o difusión de la misma. Las razones para tal desvalorización -tanto a nivel administrativo sancionador como penal- no encuentran una explicación uniforme en los distintos ordenamientos jurídicos como pudiera parecer en un primer momento y como equivocadamente es presentado por el legislador. La pluralidad de intereses en juego que se presentan en las interrelaciones que se desarrollan en el mercado de valores con interdependencia informativa y los distintos modelos de comprensión del mercado de valores para efectos de su regulación -que redundan en una distinta función que el derecho puede cumplir en ellos- explican la existencia de distintos modelos de protección en el abuso de información privilegiada. Estos últimos dependen de si la regulación y la sanción se orientan a la protección de uno o varios de dichos intereses.

Es posible, a modo de explicación, que se puedan distinguir al menos tres modelos de protección. Un primer modelo de protección ${ }^{4}$ concibe el injusto ya sea como la violación de una relación fiduciaria (fiduciary duty theory) o como una especie de apropiación indebida

\footnotetext{
${ }^{3}$ BASCUÑÁN RODRIGUEZ, "La regulación de la información privilegiada", cit. nota n 2, pp. 89 - 90.

${ }^{4}$ En la literatura chilena sobre la evolución de los modelos en el derecho estadounidense, precisamente origen de este modelo de protección, véase en detalle RIED UNDURRAGA, "Fundamentos de la Prohibición", cit. nota $\mathrm{n}^{\mathrm{o}}$ 2, pp. 439 - 463; GUZMÁN ANRIQUE, Información Privilegiada, cit. nota $\mathrm{n}^{\circ}$ 2, pp. 20 - 41; en la literatura española véase HERNÁNDEZ SAINZ, Esther, El abuso de información privilegiada en los mercados de valores, Pamplona: Thomson Civitas, 2007, pp. 215 - 227; en la literatura alemana MENNICKE, Petra, Sanktionen gegen Insiderhandel, Berlin: Editorial Duncker \& Humblot, 1996, pp. 261 - 276.
} 
GARCÍA PALOMINOS, Gonzalo. "Modelo de protección en normas administrativas y penales que regulan el abuso de Información Privilegiada en la legislación chilena".

de información privada (misappropriation theory) ${ }^{5}$ por parte de quienes, teniendo un deber fiduciario para con la empresa emisora de valores que la cedió o confió, o respecto de quién se apropió indebidamente, utilizan dicha información en su propio beneficio. En otras palabras, se trata de un modelo que se basa en la defraudación de ciertas expectativas surgidas de las relaciones bilaterales (normalmente contractuales, ya sea laborales o de prestación de servicios) que mantiene un emisor de valores y ciertos sujetos ligados a él y, por lo mismo, orientada sólo a la protección de la propiedad del emisor sobre cierta información proveniente de su seno ${ }^{6} \mathrm{y}$ del valor patrimonial de la misma. ${ }^{7}$ Este modelo tiene, sin embargo, un punto de partida diferente al que se podría esperar. Detrás de esta concepción orientada a los intereses del emisor, se desarrolla la idea que los ordenamientos que no prohíben el uso de información privilegiada asignan la propiedad de la información confidencial generada al interior de un emisor a los insider que tuvieran acceso a ella, pudiendo estos aprovecharse de la misma. Por el contrario, aquellos ordenamientos que prohíben el uso de dicha información -como el caso chileno- estarían asignando la propiedad de la misma al emisor (empresa), único que podría usarla y beneficiarse lícitamente de ella. Bajo este modelo -en que se pensaría que lo más razonable es asignar la propiedad de la información a quien la generó- quien ejerce el derecho de propiedad sobre la información no serían sus agentes -es decir, directores, gerentes, etc. (insider)-, sino la sociedad emisora misma. De esta manera, bajo este modelo de asignación de propiedad, el punto de partida son los intereses del emisor en la propiedad sobre su información y en el valor patrimonial de esta, mientras que el injusto está representado por el mal uso de esta por parte de quienes, en razón de su posición o cargo dentro de la empresa o relación

\footnotetext{
${ }^{5}$ La apropiación indebida, a diferencia de lo que han planteado algunos autores en la literatura, también se basa en la defraudación de deberes de fidelidad o confiabilidad, pero esta vez con la fuente de la información que, a su vez, mantiene una relación fiduciaria con el emisor [ejemplo de claridad en este sentido, caso United States v. O'Hagan, 521 U.S. 642 (1997)]; esta teoría presenta importantes deficiencias desde la perspectivas de los modelos de protección, ya que no es posible determinar un interés jurídicamente protegido, sino que múltiples intereses desvinculados entre sí. Las razones de dicha deficiencia es que este modelo sólo responde a la necesidad de cumplir el requisito del art. 10 b) de la Securities Exchange Act de utilizar medios engañosos o manipuladores; MENNICKE, Sanktionen gegen Insiderhandel, cit. nota. $\mathrm{n}^{\circ}$ 4, pp. 267 - 271; en Chile véase GUZMÁN ANRIQUE, Información Privilegiada, cit. nota $\mathrm{n}^{\circ} 2$, pp. 36 - 43. Este autor se expresa a favor de la interpretación de las infracciones actuales en base a este modelo (p. 83); RIED UNDURRAGA, "Fundamentos de la Prohibición", cit. nota n 2, pp. 458 - 462.

${ }^{6}$ Sobre el particular, en la literatura chilena, véase RIED UNDURRAGA, "Fundamentos de la Prohibición", cit. nota ${ }^{\circ} 2$, pp. 454 - 462; GUZMÁN ANRIQUE, Información Privilegiada, cit. nota n² 2, pp. $24-25$ y 41 - 42; en literatura española LÓPEZ BARJA DE QUIROGA, Jacobo, "El Insider Trading", Anuario de Derecho Penal y Ciencias Penales, Tomo XLVI, año MCMXCIII, p. 1039; OTTO, Harro, "Der Missbrauch von InsiderInformationen als abstraktes Gefährdungsdelikt”, en: SCHÜNEMANN, Bernd; SUÁREZ, Carlos (Ed.), Bausteine des europäischen Wirtschaftsstrafrechts, Madrid-Symposium für Klaus Tiedemann, Editorial Carl Heymanns, Köln, Berlin, Bonn, München, 1994, pp. 447 - 453.

${ }^{7}$ Para el derecho penal, a diferencia del derecho civil, los conceptos patrimonio y propiedad son diferentes. Mientras el concepto de propiedad mantiene su conceptualización y alcances propios del derecho privado, el concepto patrimonio recibe un tratamiento especial más allá del alcance del derecho subjetivo de propiedad. Se trata de un concepto que trata de abarcar los perjuicios para el dueño de un bien que tienen carácter jurídico -imposibilidad de usar, gozar o disponer-, o económico -la disminución del valor económico sobre los que se ejerce un poder de aprovechamiento sobre el bien y que se ven disminuidos, aun cuando no se pierde el derecho sobre el mismo-, etc.; véase en la literatura chilena ROJAS, Luis Emilio, "Perjuicio Patrimonial e Imputación Objetiva", Revista de Derecho de la Pontificia Universidad Católica de Valparaíso: Vol. XXXVII, $2^{\circ}$ Semestre de 2011, pp. 417 - 420.
} 
Polít. crim. Vol. 8, № 15 (Julio 2013), Art. 2, pp. 23 - 63.

[http://www.politicacriminal.cl/Vol_08/n_15/Vol8N15A2.pdf]

fiduciaria para con la empresa, se le haya cedido en confianza. De este punto de vista, al ser la información privada (o aún no pública) un bien privado, será el emisor quien podría optar por permitir o prohibir su uso según sus intereses. ${ }^{8}$ Al mismo tiempo, y desde las distintas explicaciones que la literatura desarrolla respecto a este modelo, surgen nuevos intereses que, si bien no son tan significativos para el derecho privado, si lo son para el derecho penal: no sólo la propiedad sobre la información se ve afectada, sino también el patrimonio ya que con la revelación de la misma se ve afectado el valor económico de dicha información (tesis patrimonial). ${ }^{9}$ No cabe duda que un modelo como este no le asigna ninguna relevancia a la institucionalización del mercado como ente que regula tanto el problema de la interdependencia informativa entre emisor y el mercado como las asimetrías informativas entre emisor y otros agentes del mercado. La compatibilidad de este modelo con la normativa nacional, debe ser acá analizada.

Adicionalmente es posible encontrar modelos que, a diferencia del anterior, se orientan a la protección de los intereses de quienes intervienen en el mercado de valores, ya no como emisores, sino como inversores. De esta orientación, y según el modelo se dirija, a su vez, a la protección de intereses individuales o colectivos, surgen tanto el modelo de protección patrimonial (individual) como el modelo de protección institucional (colectivo).

El primer modelo, de protección individual del inversor, se basa en la idea que las conductas de abuso de información privilegiada - esta vez en las relaciones anónimas y multilaterales propias del mercado de valores secundario - tienen la capacidad de dañar el patrimonio de algún inversor que realiza una disposición patrimonial como contraparte "anónima" del insider. Por su parte, el modelo colectivo o institucional ubica las razones para la desvalorización de dichas conductas y justifica las infracciones administrativas y penales en la idea que las conductas de abuso de información privilegiada tienen la capacidad de afectar el correcto funcionamiento del mercado de valores o la confianza en dicho mercado. ${ }^{10}$ El injusto administrativo y penal, según la orientación de cada uno de

\footnotetext{
${ }^{8}$ GUZMÁN ANRIQUE, Información Privilegiada, cit. nota $\mathrm{n}^{\circ}$ 2, p. 132

${ }^{9}$ Véase, por ejemplo, GUZMÁN ANRIQUE, Información Privilegiada, cit. nota n 2, pp. 127 - 137.

${ }^{10}$ En la literatura chilena SALAH ABUSLEME, Responsabilidad por uso de Información Privilegiada, cit. nota $\mathrm{n}^{\circ} 2$, pp. $56-59$ y p. 69 ; sobre la capacidad de función y el proceso de formación de precios y la función de posicionamiento (Allokation) véase STIPP, El Delito de Abuso de Información Privilegiada, cit. nota n ${ }^{\circ}$, p. 76; en sentido de la dependencia del funcionamiento del sistema de la transparencia véase FOXLEY, Alejandro, en: Actas de Formación de la Ley 19.301 de 1994, Sesión del Senado 15.10. 1993, Legislatura $327^{\mathrm{a}}$, Extraordinaria, pp. 20 - 21y Sesión 22a ${ }^{\mathrm{a}}$ 11. 01. 1994, Legislatura $327^{\mathrm{a}}$, Extraordinaria, p. 14; en sentido de eficiencia del mercado véase RIED UNDURRAGA, "Fundamentos de la Prohibición", cit. nota n 2, pp. 439 - 452; GUZMÁN ANRIQUE, Información Privilegiada, cit. nota $\mathrm{n}^{\circ}$ 2, pp. 107 - 115; en el sentido de pérdida de efectividad en razón de la falta de confiabilidad de los signos del mercado véase ONFRAY VIVANCO, "Ilícitos contra la información", cit. nota ${ }^{\circ} 2$, pp. 79; en el sentido de pérdida de efectividad véase MONTENEGRO, Alex (Tesis de grado), Tutela penal de la Información privilegiada en la Ley 18.045 sobre mercado de valores, Memoria para optar al grado de Licenciado en ciencias jurídicas y sociales, Pontificia Universidad Católica de Chile, Valparaíso, Chile, 2004, p. 42.; en la literatura española, véase por todos, GÓMEZ INIESTA, Diego, La utilización abusiva de información privilegiada en el mercado de valores, Madrid: McGraw Hill, 1997, pp. 201 - 206 y 246 - 286; MONROY ANTÓN, Antonio, El Delito de Abuso de Información Privilegiada en el Mercado de Valores, Madrid: Dijusa Verlag, 2006, pp. 150 - 160; BAJO FERNÁNDEZ, Miguel, "Uso de información privilegiada", en: El nuevo Código penal: presupuestos y
} 
GARCÍA PALOMINOS, Gonzalo. "Modelo de protección en normas administrativas y penales que regulan el abuso de Información Privilegiada en la legislación chilena".

estos modelos, será diferente y exigirá la configuración de conceptos normativos -tales como el de mercado de valores (o en su defecto el establecimiento de ámbitos de aplicación concreta), el del objeto de la acción como el concepto de instrumento financiero o valor de oferta pública o el de información privilegiada - de manera coherente con su punto de partida $\mathrm{y}$, en algunos casos, hasta excluyentes entre sí (según sea el modelo). ${ }^{11}$ Precisamente, la falta de comprensión de dicha pluralidad de fundamentos y modelos es fuente de discursos contradictorios y difusos de nuestro legislador, situación que, a su vez, ha generado confusiones importantes en la doctrina y jurisprudencia. ${ }^{12}$ En efecto, consecuencia de lo anterior es que la escasa doctrina nacional ${ }^{13}$ se haya debatido entre estos modelos -o hayan construidos modelos eclécticos poco sistemáticos-, influyendo de manera importante en la falta de coherencia de nuestras sentencias en sede administrativosancionador ${ }^{14}$ y penal $^{15}$ y que, de manera práctica, redundaban en el límite de la aplicación tanto del tipo administrativo como penal, como por ejemplo en la naturaleza de la información y el sujeto activo de la infracción.

c) Según lo señalado, parte importante de la problemática tiene como origen que una parte de la doctrina, asumiendo o una teoría neoclásica de la economía ${ }^{16} \mathrm{o}$ del análisis económico del derecho ${ }^{17}$ haya optado por concebir el injusto del abuso de información privilegiada según el modelo norteamericano o de protección individual del emisor (fiduciary duty theory o misappropriation theory) aprovechando la remisión expresa del legislador a los

fundamentos, Libro Homenaje al Prof. Dr. D. Ángel Torío López, Granada: Comares, 1999, p. 643; BAJO FERNÁNDEZ, Miguel; BACIGALUPO, Silvina, Derecho Penal Económico, Madrid: Ramón Areces, 2001, p. 523; en la literatura alemana véase GEHRMANN, Philipp, Das versuchte Insiderdelikt, Baden Baden: Editorial Nomos, 2009, p. 96 - 104; HIENZSCH, André, Das deutsche Insiderhandelsverbot in der Rechtswirklichkeit, Nomos Verlag, 2005, p. 195; SETHE, Rolf, "§ 12 WpHG Insiderrecht", en:

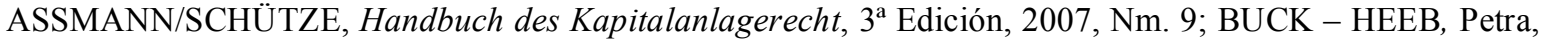
Kapitalmarktrecht, "§ 1 II", Editorial C. F. Müller, Heidelberg, 2008, Nm. 11; MERKT, Hanno; ROSSBACH, Oliver. "Zur Einführung: Kapitalmarktrecht”, Juristische Schulung, Zeitschrift für Studium und Ausbildung, C. H. Beck: München, Frankfurt a. M., 2003, p. 217.

11 Un análisis de cada modelo en SALAH ABUSLEME, Responsabilidad por uso de Información Privilegiada, cit. nota $\mathrm{n}^{\circ}$ 2, pp. $88-141$.

12 Ejemplos de opciones asistemáticas, desde el punto de vista normativo: RIED UNDURRAGA, "Fundamentos de la Prohibición", cit. nota n², o eclécticas VÁSQUEZ PALMA, "Revisión del ámbito de aplicación subjetivo", cit. nota ${ }^{\circ} 2$.

${ }^{13}$ Véase GUZMÁN ANRIQUE, Información Privilegiada, cit. nota ${ }^{\circ} 2$, p. 167; ALCALDE RODRÍGUEZ, "Uso de Información Privilegiada", cit. nota n ${ }^{\circ}$, p. 11.

${ }^{14}$ Véase Oficio Circular № 2506 de la SVS., de 10 de Julio de 1987; véase, como ejemplo de confusión en los modelos de protección, el caso Consorcio/Banco de Chile 2 donde el $20^{\circ}$ Juzgado Civil de Santiago (Causa Rol N²343-01), confirmado por la Corte de Apelaciones (Rol. $\mathrm{N}^{\circ}$ 10471-01), siguió el modelo de protección individual del emisor, mientras que en la misma causa, revocando la sentencia anterior, la Corte Suprema en Causa Rol No 4930-04 de 27 de Octubre de 2005, considerandos $19^{\circ}$ y siguientes, reorienta los fundamentos y sostiene los planteamientos del modelo de protección institucional.

${ }^{15}$ Un ejemplo de incoherencia producida en materia penal por la falta de claridad sistemática, es la sentencia del caso Inverlink (sentencia de la I. Corte de Apelaciones en Causa Rol $N^{\circ}$ Criminal 992-2010) en que, en contra de lo expresado textualmente por la Ley $\mathrm{N}^{\circ} 18.045$, se hace aplicable extensivamente el modelo de protección institucional al mercado de valores cuyo emisor no es una empresa particular, sino el Estado.

${ }^{16}$ Véase FILIPIUK, Bogna, Transparenz der Risikoberichterstattung, Wiesbaden: Gabler Ed. Wissenschaft, 2008 , p. 76.

${ }^{17}$ BASCUÑÁN RODRÍGUEZ, “La regulación de la información privilegiada”, cit. nota nº 2, p. 90. 
Polít. crim. Vol. 8, № 15 (Julio 2013), Art. 2, pp. 23 - 63.

[http://www.politicacriminal.cl/Vol_08/n_15/Vol8N15A2.pdf]

fundamentos de las regulaciones de los países desarrollados que equivocadamente los entendía como un modelo único. ${ }^{18}$ Esta teoría que había sido desarrollada administrativamente durante la primera etapa de desarrollo de la Ley $\mathrm{N}^{\circ} 18.045$ (hasta 1994), ${ }^{19}$ ha sido abandonada paulatinamente por la jurisprudencia administrativa y judicial (aunque no por una parte de la doctrina). ${ }^{20}$ Quizás su manifestación contemporánea más importante lo constituya la sentencia del vigésimo juzgado Civil de Santiago y Corte de Apelaciones de Santiago en el caso Banco de Chile (Consorcio) que entendió el injusto infraccional como la violación de deberes fiduciarios de "honestidad, fidelidad y silencio" entre los que emplearon la información y su fuente (protección del patrimonio de la empresa sobre la información), sentencia que, sin embargo, fue revocada finalmente por la Corte Suprema. $^{21}$

La importancia de tratar este tema -que, si bien no ha sido intensamente trabajado por la doctrina, pero parecía zanjado por la jurisprudencia- dice relación con que, por un lado, dicha solución no ha sido del todo clara ni sistemática, provocando decisiones poco coherente por nuestros tribunales, y, por otro, que la modificación del art. 165 de la Ley 18.045 de Mercado de Valores por la Ley $N^{\circ} 20.382$ de 2009 ha reavivado la discusión académica en torno al modelo de protección chileno y agregado un aspecto sistemáticonormativo a la discusión. ${ }^{22}$

\section{Estado de la discusión en Chile: Tensiones en la literatura chilena y las consecuencias sistemáticas de los modelos propuestos.}

a) El origen en Chile de la prohibición del uso de información privilegiada es el producto de un desarrollo normativo relativamente reciente. Su inicio puede ubicarse junto con el primer intento por regular el mercado de valores en Chile el año 1981 (Ley $\mathrm{N}^{\circ} 18.045$ de Mercado de Valores (en adelante, "LMV"), publicada en el diario oficial el 22 de Octubre de 1981$)^{23}$, normativa que responde, en palabras del legislador, a la necesidad de impulsar

\footnotetext{
${ }^{18}$ Véase conclusiones de RIED UNDURRAGA, "Fundamentos de la Prohibición", cit. nota n 2, pp. 462 - 463 ; una especial defensa al modelo norteamericano desde una perspectiva histórico-legislativo véase RIED UNDURRAGA, "El Caso Consorcio 2 - Banco de Chile”, cit. nota n², pp. $31-41$.

${ }^{19}$ GUZMÁN ANRIQUE, Información Privilegiada, cit. nota ${ }^{\circ} 2$.

${ }^{20}$ Véase COLLAO MANSILLA, Patricio, (Tesis de Grado), De la Información privilegiada en la Ley de Mercado de Valores, Universidad de Chile, Santiago de Chile, 1998, p. 93; RIED UNDURRAGA, "Fundamentos de la Prohibición", cit. nota n²; GUZMÁN ANRIQUE, Información Privilegiada, cit. nota n², pp. 165 - 168; PALMA JARA, Eduardo, (Informe en Derecho del Caso Lan Chile/Piñera), Adquisición de acciones Lan Airlines S.A., Inversiones Santa Cecilia S.A., Santiago de Chile, 24 de Enero de 2007, en: Actas del Caso Lan Chile/Piñera (Tomo I). (http://www.japonica.cl/Pinera/TomoI.pdf), pp. 26 - 31 y pp. 245 $-247$.

${ }^{21}$ Véase en extenso en: RIED UNDURRAGA, "El Caso Consorcio 2 - Banco de Chile", cit. nota $\mathrm{n}^{\circ} 2$; GUZMÁN ANRIQUE, Información Privilegiada, cit. nota $\mathrm{n}^{\circ} 2$, pp. 83; Sentencia Definitiva de la Corte Suprema en Causa Rol N 4930-04 de 27 de Octubre de 2005, considerandos $19^{\circ}$ y siguientes.

22 Discusión en torno al modelo y las modificaciones en VÁSQUEZ PALMA, "Revisión del ámbito de aplicación subjetivo", cit. nota $n^{\circ} 2$, pp. $242-249$.

${ }^{23}$ Sobre la evolución histórica ver en extenso en: PRADO PUGA, "Acerca del concepto de Información Privilegiada", cit. nota ${ }^{\circ}$ 2, pp. 237; RIED UNDURRAGA, "Fundamentos de la Prohibición", cit. nota $n^{\circ} 2$, pp. 440; SALAH ABUSLEME, Responsabilidad por uso de Información Privilegiada, cit. nota $\mathrm{n}^{\circ} 2, \mathrm{pp}$. 143;
} 
GARCÍA PALOMINOS, Gonzalo. "Modelo de protección en normas administrativas y penales que regulan el abuso de Información Privilegiada en la legislación chilena".

un mercado que reuniera condiciones eficientes de operar, institucionalizando sistemas, mecanismos e instrumentos eficaces para lograr, en lo posible, un mercado caracterizado por la equidad, orden y transparencia, la amplia difusión de la información, la competencia y el profesionalismo. ${ }^{24}$ Para dichos efectos se consideró necesario incorporar ciertos estándares éticos como sustentadores de las normas de conducta de quienes intervienen en dicho mercado. ${ }^{25}$ Junto con lo anterior, y con el objetivo de procurar eficiencia y orden, la Ley estableció un Título III denominado "De la Información Continua y Reservada", que se fundamentó en la necesidad de solucionar los importantes problemas de asimetrías de información que se observaban en el mercado de valores chileno. Con dicha finalidad se estableció, por una parte, la obligación o deber de revelar todo hecho esencial, de manera de garantizar a los inversores una mayor cantidad de información y transparencia. Mientras que, por otra parte, y para el caso en que dicha información aún no hubiese sido informada al mercado o debiera mantenerse en reserva, se establecieron dos deberes. Por una parte, el deber de no difundirla y, por otra, la prohibición a determinados "internos" de las empresas -entre ellos los directores, administradores, etc.- de valerse de dicha información "aún no divulgada" para obtener ganancias o revelar dicha información para que terceros pudieran valerse de ella. ${ }^{26}$ Para parte de la literatura dicha estructura obedecería precisamente a la estructura del modelo protección individual de la propiedad del emisor sobre su información (fiduciary duty theory o misappropriation theory). Esto, porque la información "privilegiada" decía relación únicamente con información mantenida en reserva y que correspondía a aquella cuyo origen o fuente era el mismo emisor. ${ }^{27} \mathrm{Al}$ mismo tiempo, se destaca -no obstante lo contradictorio con su fundamentación original y la naturaleza de la información reservadael contenido de las sanciones asociadas a estas conductas. ${ }^{28}$ Mientras la fundamentación de la prohibición es ecléctica y dice relación tanto con la protección de intereses de la generalidad de los inversores (asimetría de la información) como con la protección individual del inversor y otros intereses de la empresa emisora, el estatuto sancionatorio es diferenciado según se tratare de una conducta que perjudique a una u otra. Así, si las

GUZMÁN ANRIQUE, Información Privilegiada, cit. nota n², pp. 47; VÁSQUEZ PALMA, "Revisión del ámbito de aplicación subjetivo", cit. nota n², pp. 246.

${ }^{24}$ Mensaje del Presidente de la República, en Actas de Formación de la Ley N ${ }^{\circ} 18.045$ de 1981, p. 65.

${ }^{25}$ Mensaje del Presidente de la República, en Actas de Formación de la Ley $\mathrm{N}^{\circ} 18.045$ de 1981, p. 65; véase al respecto en SALAH ABUSLEME, Responsabilidad por uso de Información Privilegiada, cit. nota $\mathrm{n}^{\circ} 2, \mathrm{p}$. 143; GIESZE, Craig R., "El análisis económico de la Información Privilegiada en el Mercado de Capitales y Valores: ¿Justicia Ineficiente?”, Revista Chilena de Derecho, Vol. 26, N 4, 1999, p. 800.

${ }^{26}$ El artículo 13 inc. $1^{\circ}$ de la Ley 18.045 expresaba: "Los directores, administradores y, en general, cualquier persona que en razón de su cargo o posición tenga acceso a información de la sociedad y de sus negocios, que aún no haya sido divulgada oficialmente al mercado por la compañía (...) y que sea capaz de influir en la cotización de los valores de la misma, deberán guardar estricta reserva”. El inciso $2^{\circ}$ del mismo artículo agregaba la prohibición de valerse de dicha información para obtener para sí o para otras ventajas mediante compra o venta de valores; y el deber de resguardar que dichos actos no sean realizados por sus subordinados o terceros de su confianza; Sobre la discusión en la Comisión Legislativa véase en SALAH ABUSLEME, Responsabilidad por uso de Información Privilegiada, cit. nota $\mathrm{n}^{\circ} 2$, pp. $144-145$.

27 Sobre la contradicción estructural entre el concepto de información privilegiada y la sanción véase VÁSQUEZ PALMA, "Revisión del ámbito de aplicación subjetivo", cit. nota n 2, p. 247 - 248.

28 RIED UNDURRAGA, "Fundamentos de la Prohibición", cit. nota n 2, p. 441; GUZMÁN ANRIQUE, Información Privilegiada, cit. nota ${ }^{\circ} 2$, pp. $48-49$. 
Polít. crim. Vol. 8, № 15 (Julio 2013), Art. 2, pp. 23 - 63.

[http://www.politicacriminal.cl/Vol_08/n_15/Vol8N15A2.pdf]

conductas perjudicaban los intereses individuales del inversor particular que transaba como contraparte anónima del insider, la sanción era renviada al derecho civil, por vía de una posible acción indemnizatoria (Art. 13 inc. $4^{\circ}$ ), mientras que se reservaba la sanción administrativa sólo para el caso en que la conducta produjera perjuicios para la empresa emisora que se veía perjudicada con la revelación de su información interna. La norma de sanción administrativa establecía como sanción la devolución "a la caja social toda utilidad que hubieren obtenido a través de transacciones de valores de la sociedad" (inc. $3^{\circ}$ ). Aun cuando de la sola lectura de dicho precepto legal es difícil ser concluyente respecto a los fundamentos del ilícito, parecen a primera vista razonables las interpretaciones de una parte de la doctrina en orden a entender que lo desvalorado radicaba ya sea en el fraude de ciertas expectativas surgidas de la relación de lealtad o relación fiduciaria existente entre el emisor (empresa) y las personas nombradas en dicho artículo (personas que en razón de su cargo o posición tienen acceso a información de la sociedad) o en la apropiación indebida de dicha información. ${ }^{29}$ Como señala expresamente Ried Undurraga:

"Si las utilidades provenientes del uso de la información privilegiada pertenecían al emisor de los valores, debemos entender que ello se debía a que el legislador consideró que el emisor era el dueño (...). Podemos aventurar, entonces, que la prohibición original del año 1981 se pudo haber fundamentado en que los directores, gerentes u otros "internos" (...), se estaban apropiando indebidamente de un bien del emisor.",

Esta tendencia llega sólo hasta aquí en su análisis histórico, haciendo depender su desarrollo posterior de las constantes menciones de los legisladores al modelo norteamericano $^{31}$ y a una visión clásica del mercado que lo vincula sólo con el derecho societario (y no con el derecho financiero), con el resultado de trabajar sobre un concepto limitado de mercado de valores que desconoce la naturaleza amplia del mismo. ${ }^{32}$ Posiblemente la modificación del art. 165 con la Ley $\mathrm{N}^{\circ} 20.382$ de 2009, esta tendencia tomará un nuevo auge.

Las consecuencias de este modelo para la interpretación de las infracciones administrativas y tipos penales actuales -que sólo fueron introducidos en etapas posteriores -no son insignificantes ni marginales. En efecto, un modelo así entendido limita el círculo de destinatarios de la norma de conducta administrativa y, con ello, el círculo de autores o "sujetos activo" de la infracción administrativa y del delito sólo a quienes tienen un deber fiduciario o de fidelidad para con la empresa emisora (Fiduciary duty theory) o a quienes se han apropiado indebidamente de la información de quienes se las han confiado, independiente de si es o no el emisor (misappropiation theory). ${ }^{33}$ Bajo estos modelos, el

\footnotetext{
${ }^{29}$ Véase RIED UNDURRAGA, "Fundamentos de la Prohibición”, cit. nota n² 2, p. 441; GUZMÁN ANRIQUE, Información Privilegiada, cit. nota ${ }^{\circ} 2$, p. 49.

${ }^{30}$ RIED UNDURRAGA, "Fundamentos de la Prohibición del Uso de la Información Privilegiada en Chile: Una visión crítica“, cit. nota $\mathrm{n}^{\circ} 2$, p. 441.

${ }^{31}$ Véase RIED UNDURRAGA, "Fundamentos de la Prohibición”, cit. nota n 2, pp. 452 - 453 y 462 - 463.

${ }^{32}$ Véase letra c) de la conclusión (o valoración final)

${ }^{33}$ Así, por ejemplo, para PRADO PUGA [“Acerca del concepto de Información Privilegiada”, cit. nota $n^{\circ} 2$, pp. 246 - 264] quien accede a la fuente de información debe promediar una relación funcional con la entidad que la genera, normalmente asentada sobre una base de una actividad de gestión estable o de confianza, como el gerente,
} 
GARCÍA PALOMINOS, Gonzalo. "Modelo de protección en normas administrativas y penales que regulan el abuso de Información Privilegiada en la legislación chilena".

emisor, y no el mercado, es el centro neurálgico del interés sobre el cual se basa la desvaloración de la conducta (infracción de un deber de lealtad o apropiación indebida) y, por lo tanto, el círculo de autores queda reducido sólo a quienes mantuvieran las relaciones antes mencionadas. ${ }^{34}$ Así, para distinguir entre los poseedores de información privilegiada que son comprendidos por el círculo de destinatarios de la norma y círculo de autores de la infracción y del delito de aquellos que no los son, se desarrolla la distinción de iniciados (insider)/ externos (outsider) y, de entre los primeros, en iniciados (insider) primarios y secundarios, etc. ${ }^{35}$ Así, las formas de acreditar las relaciones fiduciarias son menos exigentes para los Iniciados (insider), mientras que más intensas para los externos (outsider), respeto de los cuales las relación fiduciaria es menos clara y debe ser acreditada. Adicionalmente, este modelo permite justificar la eliminación de los controladores de una sociedad del círculo de destinatarios de la norma (y, con ello, del círculo de autores de las infracciones y delitos), en razón de ser los creadores y propietarios de la información.

A su vez, la configuración del concepto de información privilegiada, funcional al modelo, exige que la fuente de la información sea el propio emisor o que se trate de información de su propiedad y, por lo mismo, excluye del ámbito de protección y comprensión de la prohibición a aquellas transacciones desarrolladas en submercados de títulos de valores mercado de capitales en sentido amplio- que no se basan en la estructura de dependencia informativa existente entre Sociedad emisora de valores/valores que representan alícuota de la sociedad o una deuda/ inversor, como por ejemplo sucedería en los mercados de derivados sobre materias primas, ya que la información sobre la que se basan las decisiones son en gran mayoría externas al emisor (por ejemplo, del mercado de la materia prima, de Forwards que dependen de índices emanados de otros mercados o una institución pública, etc.). Coherente con dicho modelo, el elemento del concepto de información privilegiada que incluye los "negocios del emitente", es interpretado limitadamente por esta parte de la doctrina como el "concerniente a hechos desarrollados en el interior de la empresa, y relativos a situaciones de administración patrimonial (dividendos, pasivos, utilidades, estrategias de negocios, balances, pérdidas importantes, opas de acciones) o a las perspectivas de desarrollo de negocios futuros (contratos importantes, inventos y descubrimientos, lanzamiento de un nuevo producto, apertura de nuevos mercados, etc.)", quedando fuera de esta conceptualización las informaciones de mercado o market informations, externas a la sociedad, que no tendrían el carácter de privilegiada o relevante para el insider trading. ${ }^{36}$ En relación al concepto de "valores" a que hace referencia el art. 164 LMV como objeto de la información, este modelo tiende a limitar al máximo la definición del inc. $1^{\circ}$ del Art. $3^{\circ}$ LMV y los armoniza con el art. 60 LMV, en el sentido de

director o ejecutivo; en la literatura chilena en: RIED UNDURRAGA, "Fundamentos de la Prohibición", cit. nota ${ }^{\circ}$ 2, pp. 439 - 446; GUZMÁN ANRIQUE, Información Privilegiada, cit. nota n², p. 20.

${ }^{34}$ Véase en GUZMÁN ANRIQUE, Información Privilegiada, cit. nota ${ }^{\circ} 2$, pp. 29 - 36 (en especial pp. 32 - 35).

35 Distinción, cuyo origen es la Directiva UE 89/592, seguida principalmente por la doctrina española. Ver: GÓMEZ INIESTA, La utilización abusiva, cit. nota $\mathrm{n}^{\circ}$ 10, pp. 179 - 190; en Chile ver: SALAH ABUSLEME, Responsabilidad por uso de Información Privilegiada, cit. nota n 2, pp. 179 - 184; ROSAS, "E1 Delito de Abuso de Información Privilegiada", cit. nota ${ }^{\circ} 2$, pp. 15 - 20.

${ }^{36}$ Véase PRADO PUGA, “Acerca del concepto de Información Privilegiada”, cit. nota n 2, p. 245. 
Polít. crim. Vol. 8, N 15 (Julio 2013), Art. 2, pp. 23 - 63.

[http://www.politicacriminal.cl/Vol_08/n_15/Vol8N15A2.pdf]

que se aplicaría sólo a "valores de oferta pública" que "representan bienes en el mercado de capitales, provenientes del interior de la sociedad emisora", ${ }^{37}$ limitando de esta forma tanto el ámbito de protección como de aplicación (mercado de la valores en sentido estricto).

Si esta interpretación es coherente con la estructura normativa correspondiente a los art. 60, 164 y siguientes de la ley 18.045, deberá ser analizado más abajo.

b) A la inversa, los modelos de protección orientados a los intereses de los inversores -ya no del emisor- también han recibido cierto desarrollo en nuestra literatura, siguiendo ya sea el modelo europeo ${ }^{38}$ o la ratio legis adoptada por el legislador a partir de la Ley 19.301 de 1994, lo que coincide con la incorporación de los primeros tipos penales. ${ }^{39}$ Mientras el modelo de protección institucional del inversor en el mercado ha logrado amplia aceptación, el modelo de protección individual del inversor (modelo patrimonial) que transa como contraparte anónima al insider no ha captado mayormente el interés de la literatura chilena. Esto último, debido a que la literatura económica ${ }^{40} \mathrm{y}_{\text {penal }^{41}}$ ha tendido a

\footnotetext{
${ }^{37}$ PRADO PUGA, “Acerca del concepto de Información Privilegiada”, cit. nota n 2, p. 245.

${ }^{38}$ Véase, por ejemplo, ROSAS, "El Delito de Abuso de Información Privilegiada”, cit. nota n 2, pp. 7 - 24; en VÁSQUEZ PALMA ["Revisión del ámbito de aplicación subjetivo", cit. nota n ², pp. 242 - 246], sin embargo, es posible advertir una orientación (u opción) ecléctica respecto al modelo, en que reconstruye el sistema normativo rescatando rasgos importantes del modelo norteamericano (p. 245), principalmente del modelo de la "equal access theory", pero declarando expresamente la protección de la confianza en el sistema, en especial, en la asimetría de la información como objeto de protección (p. 246).

${ }^{39}$ Intervención Superintendente de Valores y Seguros, Actas de Formación de la Ley 19.301 de 1994, Sesión del Senado 15 Octubre de 1993, Legislatura 327a, Extraordinaria, pp. 98; sobre los objetivos del legislador ver: LUCO, Nicolás, "Protección a los accionistas minoritarios frente a la toma de control de una sociedad anónima abierta", Revista Chilena de Derecho, Vol. 22, N 3, 1995, p. 417; RIED UNDURRAGA, "Fundamentos de la Prohibición", cit. nota n², pp. 449 - 452; CANALES, Información Privilegiada en la Ley del Mercado de Valores, cit. nota ${ }^{\circ} 2$, p. 20.

40 Véase HADDOCK, David; MACEY, Jonathan, "A Coasian Model of Insider Trading", Northwestern University Law Review, Vol. 80, 1986, p. 1469; HOPT, Klaus; WILL, Michael, Europäisches Insiderrecht, Stuttgart: Enka (1973), pp. 47 - 48; SETHE, “§ 12 WpHG Insiderrecht”, cit. nota n 10, Nm. 6; SOESTERS, Frank, Die Insiderhandelsverbote des Wertpapierhandelsgesetzes, Frankfurt a. M: Editorial Peter Lang, , 2002, p. 41. Sobre este tema, en la literatura chilena, véase GUZMÁN ANRIQUE, Información Privilegiada, cit. nota $\mathrm{n}^{\circ} 2$, pp. $99-107$.

${ }^{41}$ Véase DINGELDEY, Thomas, Insider Handel und Strafrecht, München: Editorial Carl Heymanns KG., p. 68; STRATENWERTH, Günter, "Zum Straftatbestand des Missbrauchs von Insiderinformationen", en: VV.AA., Festschrift für Frank Vischer, Zurichg: Editorial Schulthess Polygrafischer, 1983, p. 670; SETHE, "§ $12 \mathrm{WpHG}$ Insiderrecht", cit. nota $\mathrm{n}^{\circ} 10$, Nm. 6; absolutamente contrarios a la tesis del daño patrimonial para el derecho penal OTTO, "Der Missbrauch von Insider-Informationen”, cit. nota n 6, p. 451 - 452; LÜCKER, Volker, Der Straftatbestand des Missbrauchs von Insiderinformationen nach dem Wertpapierhandelsgesetz (WpHG), Köln: Carl Heymanns Verlag, 1998, pp. 200 - 205; HEISE, Detlef, Der Insiderhandel an der Börse und dessen strafrechtliche Bedeutung, Frankfurt a. M.: Peter Lang Verlag, 2000, p. 84; ZIOUVAS, Dimitris, Das neue Kapitalmarktstrafrecht Europäisierung und Legitimation, Köln: Editorial Carl Heymanns, 2005, pp. 180 - 190; DOUKLIAS, Sotirios, Der börsenorientierte Anlageschütz und seine strafrechtliche Absicherung, München: Editorial Herbert Utz, 2007, pp. 88 - 95; sobre la posibilidad de consecuencias negativas a causa de la transacción de los iniciados (insider) para el inversor véase PETERS, Peter A., Das deutsche Insiderstrafrecht unter Berücksichtigung strafrechtlicher Konsequenzen für Kreditinstitute und prozessualer Durchsetzung, Frankfurt a. M.: Editorial Peter Lang, 1997. p. 19; LÜCKER, Der Straftatbestand des Missbrauchs von Insiderinformationen, cit. nota $\mathrm{n}^{\circ} 41$, p. 20 y NERLICH, Heirich,
} 


\section{GARCÍA PALOMINOS, Gonzalo. "Modelo de protección en normas administrativas y penales que regulan el abuso de Información Privilegiada en la legislación chilena".}

desmitificar y rechazar la supuesta relación de causalidad entre la conducta del insider y la decisión del inversor que transa valores al mismo tiempo que el primero (contraparte anónima), lo que restringiría las posibilidades de crear un modelo sancionatorio basado en un "mito" de la lesividad patrimonial y limitaría las posibilidades del derecho civil de aceptar indemnizaciones de perjuicio por los actos de los insider que transa como contraparte de la víctima (inversor). ${ }^{42}$

Die Tatbestandsmerkmale des Insiderverbots nach dem Wertpapierhandelsgesetz, Osnabrück: Universitätsverlag Rasch, 1999, pp. 30 - 31.

${ }^{42}$ Así por ejemplo, la literatura alemana (PETERS, Das deutsche Insiderstrafrecht unter Berücksichtigung, cit. nota $\mathrm{n}^{\circ}$ 41, pp. 19 - 21; LÜCKER, Der Straftatbestand des Missbrauchs von Insiderinformationen, cit. nota $n^{\circ} 41$, p. 20 y NERLICH, Die Tatbestandsmerkmale des Insiderverbots, cit. nota $n^{\circ} 41$, pp. $30-31$ ) explica el rechazo de la tesis del daño patrimonial diferenciando dos constelaciones. a) Según si el Inversor supuestamente perjudicado se encuentra ubicado en la posición contraria a la del iniciado (insider) (ej. El insider vende y el inversor compra o viceversa) o b) si se encuentra en la misma posición o dirección del insider (ej. el insider vende y el inversor supuestamente perjudicado también vende o viceversa). Así, para la primera constelación (contraparte anónima), según LÜCKER, Der Straftatbestand des Missbrauchs von Insiderinformationen, cit. nota $\mathrm{n}^{\circ} 41$ p. 21) sólo es posible entender un perjuicio patrimonial si se entiende que el inversor ha transado "bajo el valor" del precio hipotético -información que tiene el insider-o sobre el valor hipotético del que ha comprado. De ahí que, como señala ZIOUVAS [Das neue Kapitalmarktstrafrecht, cit. nota $\mathrm{n}^{\circ} 41$, p. 181], se relacione el daño patrimonial con aquella ganancia que el inversor ignorante de las informaciones positivas no ha podido realizar o de las pérdidas que este no ha podido impedir. Sin embargo, la opinión mayoritaria (véase LÜCKER, Der Straftatbestand des Missbrauchs von Insiderinformationen, cit. nota $\mathrm{n}^{\circ}$ 41, p. 200; HEISE, Der Insiderhandel, cit. nota $\mathrm{n}^{\circ}$ 41, p. 84; ZIOUVAS, Das neue Kapitalmarktstrafrecht, cit. nota ${ }^{\circ}$ 41, pp. 180 - 185; DOUKLIAS, Der börsenorientierte Anlageschütz, cit. nota $n^{\circ} 41$, pp. 88 - 90) basa su rechazo es dos ideas importantes: la conducta del insider no tiene la capacidad de influir causalmente en la decisión del inversor de comprar o vender al mismo tiempo. Así, por ejemplo, independiente de si la información es positiva o negativa (de manera extensa NERLICH, Die Tatbestandsmerkmale des Insiderverbots, cit. nota $\mathrm{n}^{\circ} 41$, pp. $30-31$ ) no es posible asociar la conducta del iniciado (insider) con la del inversor, con lo cual no podría acreditarse que sin la conducta del iniciado (insider) el "inversor" se habría comportando de una forma distinta. Otra idea dice relación con la distinción entre información positiva o negativa para el valor y si el inversor compra o vende. Así, los argumentos de la falta de causalidad se dirigen a todas las constelaciones, mientras que estos últimos tendrían la capacidad de eliminar algunas de ellas. Por ejemplo, cuando la información afecta positivamente el valor hipotético y el inversor compra, no existiría ningún daño patrimonial; como tampoco existiría si la información es negativa y el inversor vende ya que ha recibido un mejor precio que el del precio hipotético. Para la segunda constelación, es decir aquella en que el inversor transa desde la misma posición o dirección que el iniciado (insider), las posiciones también son encontradas. Una parte de la literatura alemana (véase por ejemplo GRUNEWALD, Barbara, "Neue Regeln zum Insiderrecht", Zeitschrift für Bankrecht und Bankwirtschaft (ZBB), 1990, pp. 129 - 130 o PFISTER, Bernhard, "Stand der Insiderdiskussion", Zeitschrift für Unternehmens- und Gesellschaftsrecht (ZGR), Vol. 10, 1981, p. 341.) ubican el desvalor del uso de información privilegiada en la idea de que el aprovechamiento de esta, por medio de su explotación, provoca un daño al inversor ya que necesariamente modifica el precio del título de valor. En efecto, para esta opinión el precio del valor en el caso de la venta del título se ve afectado a causa de la presión hacia el alza de la oferta y la presión hacia el alza de demanda como consecuencia [LÜCKER, Der Straftatbestand des Missbrauchs von Insiderinformationen, cit. nota $n^{\circ} 41 \mathrm{pp}$. 22 - 23]. Que la afectación de una correcta formación del precio pueda provocar un perjuicio patrimonial a la contraparte anónima es rechazado por la doctrina dominante [véase en NERLICH, Die Tatbestandsmerkmale des Insiderverbots, cit. nota $\mathrm{n}^{\circ} 41$, p. 30]. Dos razones se esgrimen: la primera se refiere a la falta de relación causal entre la conducta del insider y la decisión de invertir del inversor; al mismo tiempo, la literatura demuestra que en un grupo importante de constelaciones el inversor se ve favorecido por un mejor y rápido desarrollo y formación del precio (GRUNEWALD, "Neue Regeln zum Insiderrecht", cit. nota n 42, pp. 128 130; LÜCKER, Der Straftatbestand des Missbrauchs von Insiderinformationen, cit. nota n 42, p. 23). 
Polít. crim. Vol. 8, No 15 (Julio 2013), Art. 2, pp. 23 - 63.

[http://www.politicacriminal.cl/Vol_08/n_15/Vol8N15A2.pdf]

Como se dijo, a diferencia del modelo de protección individual del inversor, el modelo de protección institucional ha recibido una mayor aceptación y desarrollo dogmático. En efecto, tanto el legislador como la literatura chilena han entendido dicha orientación vinculada o con la transparencia -entendida esta como la capacidad de acceder a toda información, pero también al acceso a una correcta formación de precios-- ${ }^{43}$ o al igual acceso a la información ${ }^{44}$, a la igualdad de oportunidades, ${ }^{45}$ el adecuado funcionamiento del mercado, ${ }^{46}$ etc. La doctrina mayoritaria considera a estos, sin embargo, sólo como objetos constitutivos del bien jurídico y no como el bien jurídico propiamente tal. El bien jurídico sería la "fe pública" o "la confianza pública" en la transparencia, el adecuado o correcto funcionamiento del mercado de valores o en la igualdad de acceso a la información. ${ }^{47}$ En el mismo sentido se han pronunciado tanto la Superintendencia de Valores y Seguros (en adelante, "SVS") ${ }^{48}$ y la Excelentísima Corte Suprema ${ }^{49}$ en el ámbito administrativo sancionador.

\footnotetext{
${ }^{43}$ Esta falta de transparencia, según la literatura, se refiere a la eficiencia del mercado, por cuanto "mientras un mercado sea más eficiente, los precios de los bienes reflejarán de forma más acertada su valor real". ONFRAY VIVANCO, ["Ilícitos contra la información", cit. nota ${ }^{\circ} 2$, pp. 79 - 80] señala que en estos delitos está comprometida la fe pública en cuanto se afecta la seguridad del tráfico jurídico, "entendiendo por tal el desarrollo normal y expedito de los negocios jurídicos que tienen como fundamento la veracidad de los signos y objeto que en ellos se emplean". Por su parte MONTENEGRO [Tutela penal de la Información privilegiada, cit. nota $\mathrm{n}^{\circ} 10, \mathrm{p} .42$ ], junto con adherir a la tesis acumulativa, añade además que el sólo hecho que alguien distorsione, en beneficio propio, el juego normal de las leyes del mercado, se traduce en "una pérdida de eficiencia de éste."; véase la intervención del Ministro de Hacienda Alejandro Foxley, en Actas de Formación de la Ley 19.301 de 1994 en Sesión del Senado 15 Octubre de 1993, Legislatura 327a, Extraordinaria, pp. 20 - 21; Sesión 22a , en 11 de enero de 1994, Legislatura 327a, Extraordinaria, p. 14)

${ }^{44}$ Ya en la primera fase de desarrollo de la Ley 18.045 de 1981 como en las posteriores era posible observar argumentos del legislador en la dirección de proteger la igualdad o igualdad de los partícipes en el mercado, principalmente inversores. En la literatura actual véase VÁSQUEZ PALMA, "Revisión del ámbito de aplicación subjetivo", cit. nota n ${ }^{\circ}$ 2, p 246.

${ }^{45}$ STIPP, El Delito de Abuso de Información Privilegiada, cit. nota ${ }^{\circ} 2$, pp. $50-51$ y p. 80 . (aunque parece optar finalmente por la idea de capacidad de funcionamiento del mercado asociados a la idea de transparencia y formación de precios.)

${ }^{46}$ STIPP, El Delito de Abuso de Información Privilegiada, cit. nota n 2, p. 80.

${ }^{47}$ Destacan en esta posición: PRADO PUGA, "Acerca del concepto de Información Privilegiada", cit. nota ${ }^{\circ}$ 2, p. 238 y p. 262; SALAH ABUSLEME, Responsabilidad por uso de Información Privilegiada, cit. nota $\mathrm{n}^{\circ} 2$, p. 215; ROSAS, "El Delito de Abuso de Información Privilegiada", cit. nota $n^{\circ} 2$, p. 7 y pp. $10-11$; MONTENEGRO, Tutela penal de la Información privilegiada, cit. nota $\mathrm{n}^{\circ} 10, \mathrm{p}$. 4 ; en parte y algo difuso ONFRAY VIVANCO, "Ilícitos contra la información", cit. nota n ${ }^{\circ}$ 2, p. 73 y p. 79; contrario y críticos a esta RIED UNDURRAGA, "Fundamentos de la Prohibición", cit. nota n² 2, pp. 449 - 450; GUZMÁN ANRIQUE, Información Privilegiada, cit. nota ${ }^{\circ} 2$, pp. $107-116$.

${ }^{48}$ Mientras la SVS ha señalado que "El bien jurídico protegido por las normas sobre información Privilegiada es la mayor igualdad posible en que debe encontrarse los que negocien en el mercado de valores" (Superintendencia de Valores y Seguros, Dictámenes del Mercado de Valores 1981 - 1999, en: Revista de Valores, Informe Interno de la Fiscalía de Valores, 1998, p. 58) y con ello relaciona la protección con una especie de derecho subjetivo a la igualdad de condiciones; Esta igualdad es concebida, sin embargo, como requisito o condición para la configuración de un mercado "equitativo, competitivo, ordenado y transparente". (Superintendencia de Valores y Seguros, Dictámenes del Mercado de Valores 1981 - 1999, en: Revista de Valores, Informe Interno de la Fiscalía de Valores, 1998, S. 560). No se trata, por tanto, de una igualdad informativa general o protección de un estado de igualdad, sino de un derecho al igual acceso a la información.
} 
GARCÍA PALOMINOS, Gonzalo. "Modelo de protección en normas administrativas y penales que regulan el abuso de Información Privilegiada en la legislación chilena".

Las consecuencias de este modelo son importantes para la interpretación de cada uno de los elementos objetivos de los tipos infraccionales y penales. En efecto, para la opinión mayoritaria el ámbito de aplicación objetivo del precepto infraccional y penal tendería a su expansión, si se compara con el modelo analizado anteriormente, ya sea extendiendo la comprensión de los objetos de la acción, (por ejemplo, del concepto de título de valor o valor de oferta pública más allá del correspondiente a los valores transados en el mercado de capitales en sentido estricto, es decir, mercado de acciones o derivados sobre las mismas) y abarcando todo tipo de títulos de valor, o entendiendo el concepto de información privilegiada más allá de la información proveniente del emisor para abarcar incluso información externa. ${ }^{50} \mathrm{~A}$ este modelo corresponde la interpretación desarrollada por la Exc. Corte Suprema cuando califica como Información privilegiada aquella relacionada con un emisor y sus valores, independientemente de si su origen o fuente es el propio emisor y sus circunstancias directas y dependientes de él o circunstancias creadas por un tercero:

“(...) la ley para determinar la calidad de privilegiada de la información no atiende a su origen, esto es, si proviene de terceros o emana de la misma persona que hace uso de ella, sino a su contenido: al hecho de no haber sido divulgada al mercado, y a la circunstancia de que ésta, por su naturaleza, sea capaz de influir en dicho mercado, en la cotización de los valores emitidos."

Coherente con esa interpretación del modelo por la Exc. Corte Suprema, la I. Corte de Apelaciones de Santiago en un fallo penal importante -aunque excesivo en su aplicación más allá del ámbito de aplicación de norma- condenó a la secretaria del presidente del Banco Central por enviar a un inversor información relevante relacionada con varios valores transados en el mercado valores, pero cuya fuente no era un emisor, sino una institución pública:

\footnotetext{
${ }^{49}$ La Corte Suprema, por otro lado, ha señalado que “(...) lo que se protege con nuestra normativa legal no es el derecho a la información, sino el derecho de los distintos operadores a intervenir en el mercado teniendo acceso igualitario a la información (...)", Corte Suprema, causa Rol N ${ }^{\circ} 3.364$ de 2006, considerando $\mathrm{N}^{\circ} 14$; véase en: GUZMÁN ANRIQUE, Información Privilegiada, cit. nota $n^{\circ}$ 2, p. 78.

${ }^{50}$ La protección de la confianza en el mercado de valores o la capacidad de funcionamiento en el mismo, por regla general en la literatura, implica la comprensión de transacciones con cualquier tipo de valores del mercado de valores, independiente de cualquier otra consideración o la comprensión de transacciones en mercados no estructuras únicamente sobre la base de la información del emisor (Ej. Mercados de derivados). Por lo mismo, comprendería transacciones en submercados distintos e independiente del nivel de organización, institucionalización, etc. Así, por ejemplo ROSAS, ["El Delito de Abuso de Información Privilegiada", cit. nota $\mathrm{n}^{\circ} 2$, p. 7], entiende que, "bajo el concepto de información privilegiada en nuestra regulación es sin duda de una tremenda amplitud, ya que quedan incluidos tanto la información relativa a hechos internos del ente emisor y que aluden a su situación de gestión administrativa o patrimonial -estados financieros, dividendos, utilidades, actividad de colocación de valores, estrategias de mercados, etc.-, como la información que se refiere a hechos externos del emisor, pero influyentes en la cotización de sus valores proyectos de fusión, de adquisición de otras empresas, etc.-, vinculados principalmente a negocios del mismo ente emisor." También de esta opinión es el Comité de Regulación y Autoregulación de la Bolsa de Comercio de Santiago, Reglas para prevenir y combatir el Uso de Información Privilegiada y la Manipulación de Mercado, Santiago. 2009, p. 4.
} 
Polít. crim. Vol. 8, № 15 (Julio 2013), Art. 2, pp. 23 - 63.

[http://www.politicacriminal.cl/Vol_08/n_15/Vol8N15A2.pdf]

"Que, además, la información privilegiada no puede referirse sólo a aquella que emana internamente del ente que emite los valores, es decir información privilegiada interna, sino que también debe incluirse dentro de este concepto normativo, aquella información que pueda emanar de agentes externos y que produzcan una situación de desequilibrio o desigualdad respecto de la información que se maneja en el mercado financiero". 51

Otro aspecto relevante dice relación con las consecuencias de la adopción de este modelo tanto para la determinación del círculo de destinatarios de la norma de conducta administrativa como del círculo de autores del delito, en que las posibilidades son diversas. ${ }^{52}$ Una parte de la doctrina entiende que los tipos penales no sólo abarcan a los iniciados (insider) primarios o secundarios o personas que tienen una relación con el emisor, sino que pueden comprender a cualquier persona que se aproveche de un conocimiento no público. En este sentido, por ejemplo, Salah señala que el Art. 165 LMV alcanza tanto a los iniciados institucionales (Organinsider) como iniciados temporales, en la medida que exista una "relación" y dicho concepto pueda ser interpretado de manera amplia, lo que implica la exclusión sólo de los extraños (outsider). ${ }^{53}$ Cuestión completamente distinta ocurriría, según Salah, en material penal en los Art. 60 letra g) y h), para quien si bien no sería posible una interpretación extensiva e ilimitada en materia administrativa, si lo sería -sorprendentemente- en material penal a causa de la cláusula general ("el que", "los que") empleada por el legislador en las letras g) y h) del art. 60.54 Aun cuando Salah se manifiesta contraria a la redacción del tipo penal, precisamente porque permitiría una extensión desproporcionada del círculo de autores, constata que esta (redacción) permitiría incluir en el tipo tanto a los extraños (outsider) como a quienes han obtenido la información de un Iniciado secundario (tippes) ${ }^{55}$ A la falta de claridad tanto sistemática como sobre la relación subsidiaria entre el derecho administrativo y penal, se suma la presentación de criterios de lege ferenda en la interpretación del sistema que llevan, por ejemplo a Guzmán, a señalar que esta fórmula seguida en materia penal sería un "descuido" del legislador, permitiendo una extensión absoluta y sin restricciones del círculo de autores. ${ }^{56}$

Por otra parte, para aquella parte de la doctrina penal que siga la idea que el abuso de información privilegiada es un delito de infracción de deber, y que ese deber es fundante de la idea de confianza o fe pública -idea no profundizada por dicha literatura-, el círculo de autores tenderá a limitarse sólo a los titulares de una especie de "deber de garante" en relación a sus deberes de información. ${ }^{57}$

\footnotetext{
${ }^{51}$ Sentencia de la I. Corte de Apelaciones en Causa Rol No Criminal 992-2010, de fecha veintidós de noviembre de dos mil once. (Caso Inverlink).

${ }^{52}$ Un análisis completo de la discusión administrativa sancionadora véase en VÁSQUEZ PALMA, "Revisión del ámbito de aplicación subjetivo", cit. nota n² 2, pp. $273-279$.

${ }^{53}$ SALAH ABUSLEME, Responsabilidad por uso de Información Privilegiada, cit. nota n 2, pp. $183-184$.

${ }^{54}$ SALAH ABUSLEME, Responsabilidad por uso de Información Privilegiada, cit. nota n ${ }^{\circ}$ 2, pp. $218-219$.

${ }^{55}$ SALAH ABUSLEME, Responsabilidad por uso de Información Privilegiada, cit. nota n ${ }^{\circ}$, pp. $218-219$.

${ }^{56}$ GUZMÁN ANRIQUE, Información Privilegiada, cit. nota $\mathrm{n}^{\circ}$ 2, p. 65.

${ }^{57}$ PIÑA ROCHEFORT, "Algunos problemas", cit. nota n ${ }^{\circ}$ 2, p. 122.
} 
GARCÍA PALOMINOS, Gonzalo. "Modelo de protección en normas administrativas y penales que regulan el abuso de Información Privilegiada en la legislación chilena".

La Corte Suprema, coherente con las conceptualizaciones anteriores, calificó de carente “de toda lógica" que para estar frente a información privilegiada se requiera necesariamente que quien la obtenga sea un tercero distinto a los internos, desde que lo que se protege con nuestra normativa legal no es el derecho a la información, sino el derecho de los distintos operadores a intervenir en el mercado teniendo un acceso igualitario a la información. ${ }^{58}$ En ese mismo sentido y refiriéndose al círculo de destinatarios de la norma, la Corte Suprema en el caso Banco de Chile fue de la idea que la ley no exige una vinculación directa entre la fuente de la información y el sujeto pasivo que accede a ella: "cualquier persona" puede ser sujeto activo del uso de información Privilegiada. ${ }^{59}$ Esta opinión de la Excelentísima Corte Suprema, sin embargo, puede verse alterada con la nueva redacción del art. 165 LMV. $^{60}$

Finalmente es posible encontrar en nuestra literatura algunas posiciones eclécticas o, al menos, que presentan aspectos poco sistemáticos en relación a la fundamentación aceptada inicialmente y que son consecuencia, por una parte, de la ya explicada incapacidad del legislador para definir -al menos en sus primeras etapas de desarrollo- un modelo determinado y, por otra, de la falta de claridad respecto a las consecuencias del modelo elegido. Un ejemplo: Vásquez Palma, en su interpretación al actual art. 165 LMV, junto con aceptar que la fundamentación de las infracciones radica en la capacidad de estas conductas para afectar la confianza en la igualdad de oportunidades para acceder a la información $^{61}$ (es decir, el modelo de protección institucional) interpreta paralelamente el círculo de destinatarios de la norma según los deberes fiduciarios propios de los iniciados (insider) primarios y exigibles, como limitación, a los iniciados secundarios o tippess ${ }^{62} \mathrm{y}$ outsider. ${ }^{63}$ De esta forma, excluye a los terceros que, no obstante tener una "relación" con el emisor o con algunos de los sujetos descritos en el art. 166 LMV, dicha relación no es de carácter fiduciaria. Las razones, en palabras de esta autora, es que el legislador posiblemente no ha querido sancionar a terceros ya que esta información ya ha pasado a ser pública, ${ }^{64}$ citando para ello fallos correspondientes al sistema norteamericano (modelo de protección individual del emisor). Lo mismo sucede en relación con los externos (outsider), para quienes esta autora sólo exige deberes de fidelidad "derivados" o, de subordinación o confianza. $^{65}$ Como es posible observar esta interpretación del sistema -que, ya hemos reconocido que es poco claro en su origen y fundamentación- confunde aspectos de dos modelos distintos (el individual orientado a la protección del emisor con el institucional orientado a la protección del inversor) y les provee un sentido poco sistemático.

\footnotetext{
${ }^{58}$ Sentencia de la Corte Suprema de Chile de 26 Julio 2006, en Causa Rol N ${ }^{\circ} 3.364-2006$, considerando $9^{\circ}$.

59 Sentencia de la Corte Suprema en causa Rol N 4930-2004 de fecha 27 de Octubre de 2005, considerandos $21^{\circ}$ y $22^{\circ}$ (Caso Banco de Chile), al respecto véase RIED UNDURRAGA, "El Caso Consorcio 2 - Banco de Chile", cit. nota $n^{\circ} 2$, p. 31 .

${ }^{60}$ Véase VÁSQUEZ PALMA, "Revisión del ámbito de aplicación subjetivo", cit. nota n 2, pp. 246 - 247.

${ }^{61}$ VÁSQUEZ PALMA, "Revisión del ámbito de aplicación subjetivo", cit. nota n 2, pp. $246-247$.

${ }^{62}$ VÁSQUEZ PALMA, "Revisión del ámbito de aplicación subjetivo", cit. nota n 2, pp. $276-277$.

${ }^{63}$ VÁSQUEZ PALMA, "Revisión del ámbito de aplicación subjetivo”, cit. nota n 2, p. 279.

${ }^{64}$ VÁSQUEZ PALMA, "Revisión del ámbito de aplicación subjetivo", cit. nota n², p. 278.

${ }^{65}$ VÁSQUEZ PALMA, "Revisión del ámbito de aplicación subjetivo”, cit. nota n² 2, p. 279.
} 
Polít. crim. Vol. 8, № 15 (Julio 2013), Art. 2, pp. 23 - 63.

[http://www.politicacriminal.cl/Vol_08/n_15/Vol8N15A2.pdf]

La opción por el modelo de protección institucional, ha sido constantemente rechazada por aquella parte de la doctrina chilena que defiende el modelo norteamericano o de protección individual del emisor. ${ }^{66}$ El principal argumento esgrimido dice relación con que ésta tendría consecuencias negativas sobre la interpretación del tipo, siendo evidente que no sería coherente con el resto del sistema y su fundamentación. Esto, principalmente, porque llevaría a sancionar conductas que desde esa perspectiva no fueron contempladas originalmente por el legislador, al punto que ni siquiera quien ha creado la información puede utilizarla en beneficio propio. ${ }^{67} \mathrm{Al}$ mismo tiempo, esta tendencia de la doctrina ha sostenido que la simetría o igualdad informativa entre las partes de un negocio es sólo un ideal que, en la realidad, no existe. En la realidad, la diferencia o asimetría en la información entre las partes sería natural y lógica, tanto así que no es sancionada para ninguna otra clase de negocios. ${ }^{6}$

Es evidente, que las críticas dirigidas merecen distintas respuestas. La primera de ellas será contestada más abajo, pero es posible adelantar que esta propuesta parece no reconocer que los deberes informativos tienen como objetivo, precisamente equilibrar las importantes asimetrías informativas. La segunda, merece recibir respuesta ahora. La crítica a la protección de la "igualdad", por parte de esta parte de la doctrina, sólo es válida para el primer grupo de propuestas, representadas por la opinión de la SVS. Sin embargo, no se dirigen al segundo grupo de propuestas y, ejemplificada aquí, por la opinión de la Corte Suprema. Según ésta, no se trata -en la fundamentación del legislador- de garantizar una absoluta igualdad entre los participantes del mercado -no protege un ideal- sino la expectativa normativa al igual acceso a la información en las instituciones del mercado de valores. Esta opinión, sin embargo, aun cuando es capaz de contestar correctamente a las críticas formuladas por la literatura, especialmente proveniente del derecho administrativo sancionador, no da respuesta de si se trata de un derecho general a la igualdad de acceso a toda la información o sólo a la garantizada en los sistemas formales del mercado de valores chileno.

c) Como se puede apreciar, la discusión respecto al modelo adoptado por la normativa chilena no ha estado exenta de problemas derivados de la falta de claridad del legislador y, en particular, por la utilización indiferenciada de planteamientos de lege lata y lege ferenda en la interpretación de las normas administrativas y penales. Se trata, sin embargo, más bien de tensiones externas al sistema, que internas del mismo. La solución a dicho problema sólo puede encontrase con la eliminación, al menos en un primer momento, de las consideraciones de lege ferenda de manera de interpretar correctamente no sólo la ratio legis, sino que además la sistemática y estructura normativa. En lo que sigue se propone una revisión sistemática e histórica, de manera de determinar si la Ley $\mathrm{N}^{\circ} 18.045$ ha dejado

\footnotetext{
${ }^{66}$ RIED UNDURRAGA, "Fundamentos de la Prohibición", cit. nota n², p. 463

${ }^{67}$ De esta opinión ALCALDE RODRÍGUEZ, "Uso de Información Privilegiada", cit. nota n², p. 15; GUZMÁN ANRIQUE, Información Privilegiada, cit. nota n 2, p. 78; Sentencia en causa Rol N C-4.394 - 1997, del $10^{\circ}$ Juzgado de Santiago, considerandos 21 y 22.

${ }^{68}$ Esta posición es especialmente intensa en la literatura norteamericana. En la literatura chilena ver en: RIED UNDURRAGA, "Fundamentos de la Prohibición", cit. nota n² 2, pp. $447-448$.
} 
GARCÍA PALOMINOS, Gonzalo. "Modelo de protección en normas administrativas y penales que regulan el abuso de Información Privilegiada en la legislación chilena".

espacio para introducción de dichas consideraciones de lege ferenda o, por el contrario, ha establecido un modelo definido.

La tesis aquí defendida es que, a diferencia de lo señalado por los defensores del modelo norteamericano en Chile, si es que existió un germen de dicho modelo en la antigua normativa de la Ley $\mathrm{N}^{\circ} 18.045$ de 1981, ya ha sido intensamente modificado (o aclarado) y la actual sistemática es el resultado de las modificaciones a la Ley 18.045 incorporadas por las Leyes $\mathrm{N}^{\circ} .19 .301$ 1994, $\mathrm{N}^{\circ} 19.705$ de 2000 y N² 20.382 de 2009. Sólo la incorporación de opiniones de lege ferenda que ignoran la sistemática normativa en la interpretación de los tipos infraccionales y penales, pueden llegar a tal resultado. El modelo chileno responde a las características del modelo de protección institucional.

\section{Punto de partida: Aclaración histórica.}

El origen en Chile de la prohibición de abuso de información privilegiada es relativamente reciente y coincide con el inicio de un proceso de institucionalización de los sistemas, estructuras y plataformas que configuran el mercado de valores chileno. ${ }^{69}$ La evolución de dicha regulación, puede ser diferenciada en tres fases de desarrollo. Una primera fase -que podemos denominar puramente administrativa - es la correspondiente al proceso que se inició con la dictación de la Ley $\mathrm{N}^{\circ} 18.045$ de Mercado de Valores, publicada en el diario oficial el 22 de Octubre de 1981, hasta antes de la dictación la Ley $\mathrm{N}^{\circ} 19.301$ de 1994. Una segunda fase de modernización lo marca la introducción de modificaciones por parte de la Ley $\mathrm{N}^{\circ} 19.301$ en 1994 a la Ley $\mathrm{N}^{\circ} 18.045$ y en que se concretiza la decisión del legislador por el modelo de protección institucional, cuestión que se manifiesta tanto en una regulación específica (titulo XXI "De la Información Privilegiada") como en el inicio de la criminalización de conductas de abuso de información privilegiada (Art. 60). ${ }^{70}$ Finalmente una tercera fase -la de perfeccionamiento de la regulación y expansión de la criminalización- lo representan las modificaciones introducidas tanto por la ley 19.705 de 2000 y, últimamente, concretada con la Ley N²0.382 de 2009.

Como ya se ha adelantado, en la primera fase (desde la dictación de la Ley $\mathrm{N}^{\circ} 18.045$ de 1981 hasta 1994), la ley de mercado de valores tuvo como objetivo institucionalizar el mercado de valores, generando sistemas de interacción caracterizados por la "equidad, orden y transparencia, la amplia difusión de la información, la competencia y el profesionalismo". ${ }^{71}$ No obstante lo anterior, el legislador fue extremadamente ecléctico y poco sistemático, utilizando para el establecimiento de normas sobre abuso de información privilegiada modelos de protección distintos, basados en formas de comprender las

\footnotetext{
${ }^{69}$ Sobre el origen de la prohibición véase PRADO PUGA, "Acerca del concepto de Información Privilegiada", cit. nota $\mathrm{n}^{\circ}$ 2, pp. 237 - 239; RIED UNDURRAGA, "Fundamentos de la Prohibición", cit. nota n², pp. 440 444; SALAH ABUSLEME, Responsabilidad por uso de Información Privilegiada, cit. nota ${ }^{\circ} 2$, pp. 143 - 150; GUZMÁN ANRIQUE, Información Privilegiada, cit. nota n 2, pp. 47 - 52; VÁSQUEZ PALMA, "Revisión del ámbito de aplicación subjetivo", cit. nota n² 2, pp. 246 - 249.

${ }^{70}$ Véase en extenso SALAH ABUSLEME, Responsabilidad por uso de Información Privilegiada, cit. nota $\mathrm{n}^{\circ}$ 2, pp. 213 - 221; GUZMÁN ANRIQUE, Información Privilegiada, cit. nota ${ }^{\circ}$ 2, pp. 50 - 51.

${ }^{71}$ Mensaje del Presidente de la República, en: Actas de Formación de la Ley N 18.045 de 1981, p. 65.
} 
Polít. crim. Vol. 8, № 15 (Julio 2013), Art. 2, pp. 23 - 63.

[http://www.politicacriminal.cl/Vol_08/n_15/Vol8N15A2.pdf]

interacciones del mercado de valores absolutamente contradictorias. Así, esta regulación se contempló como una forma de enfrentar la necesidad de solucionar los importantes problemas de asimetrías de información que se observaban en el mercado de valores chileno previo a esta institucionalización. Sin embrago, su cristalización en normas de conductas y de sanción concretas sólo se vinculó a una de las constelaciones problemáticas de asimetría informativa: aquella que se producía entre los inversores y determinados internos de la empresa emisora que, estando facultados para no informar sobre un hecho esencial en atención al interés del emisor (una excepción a las normas que garantizaban altos niveles de información y transparencia), podían aprovecharse de ella durante el tiempo de la reserva ya sea usándola y obteniendo ganancias o revelando dicha información para que terceros pudieran valerse de ella. ${ }^{72} \mathrm{Si}$ a este marco de aplicación reducido se agrega al análisis el estatuto sancionatorio equivoco -devolución "a la caja social toda utilidad que hubieren obtenido a través de transacciones de valores de la sociedad" (art. 13 inc. $3^{\circ}$ ) - no era de extrañar que tanto la literatura como la jurisprudencia tuvieran importantes razones sistemático-normativas para interpretar la prohibición desde el modelo de protección de la propiedad del emisor.

Fue la Ley $\mathrm{N}^{\circ} 19.301$ de 1994, en una segunda fase de modernización, sin embargo, la que proveyó a la Ley $\mathrm{N}^{\circ} 18.045$ de 1981, sobre Mercado de Valores, mayor claridad sistemática. Dicha ley introdujo tanto el titulo XXI "De la Información Privilegiada" como también tipos penales que sancionan el uso de la misma (Art. 60). ${ }^{73}$ La introducción de tipos penales, sin embargo, se enmarca dentro de un proyecto cuyos objetivos excedían la mera prohibición y sanción y que se relacionaban con la idea general de “(...) hacer más eficiente la intermediación de recursos de ahorro para inversión (...) a través de una mejor regulación de los conflictos de intereses, con el fin de aumentar la transparencia, seguridad y equidad en el mercado." 74 De la lectura del proyecto y de las opiniones de los legisladores, es evidente que la regulación referida a la información privilegiada se enmarcó en la discusión y solución de problemas relacionados con los conflictos de intereses $^{75}$, en especial, el conflicto entre ser partícipe del mercado valores y la

\footnotetext{
${ }^{72} \mathrm{El}$ artículo 13 inc. $1^{\circ} \mathrm{LMV}$ expresaba: "Los directores, administradores y, en general, cualquier persona que en razón de su cargo o posición tenga acceso a información de la sociedad y de sus negocios, que aún no haya sido divulgada oficialmente al mercado por la compañía (...) y que sea capaz de influir en la cotización de los valores de la misma, deberán guardar estricta reserva”. El. inc. $2^{\circ}$ del mismo artículo agregaba la prohibición de valerse de dicha información para obtener para sí o para otras ventajas mediante compra o venta de valores; y el deber de resguardar que dichos actos no sean realizados por sus subordinados o terceros de su confianza; sobre la discusión en la Comisión Legislativa véase SALAH ABUSLEME, Responsabilidad por uso de Información Privilegiada, cit. nota ${ }^{\circ} 2$, pp. $144-145$.

${ }^{73}$ SALAH ABUSLEME, Responsabilidad por uso de Información Privilegiada, cit. nota n², pp. 213 - 221; GUZMÁN ANRIQUE, Información Privilegiada, cit. nota n 2, pp. 50 - 51.

${ }^{74}$ Véase Actas de Formación de la Ley 19.301 de 1994, en Actas de Sesión del Senado 15 Octubre de 1993, p. 2; Intervención del Sr. Ministro de Hacienda Alejandro Foxley, Actas de Formación de la Ley 19.301 de 1994 en Sesión del Senado 15 Octubre de 1993, Legislatura 327 ${ }^{\mathrm{a}}$, Extraordinaria, p. 18; Intervención Superintendente de Valores y Seguros, Actas de Formación de la Ley 19.301 de 1994 en Sesión del Senado 15 Octubre de 1993, Legislatura 327 $7^{\mathrm{a}}$, Extraordinaria, p. 25.

${ }^{75}$ Intervención del Superintendente de Valores y Seguros, en Actas de Formación de la Ley 19.301 de 1994 , Primer Informe Comisión de Hacienda, 15 Octubre de 1993, pp. 30 - 31; sobre la relación entre la prohibición y la información privilegiada véase la intervención del Senador Miguel Otero, en Acta Sesión $22^{\mathrm{a}}$ de 11 de
} 
GARCÍA PALOMINOS, Gonzalo. "Modelo de protección en normas administrativas y penales que regulan el abuso de Información Privilegiada en la legislación chilena".

participación en la administración de emisores de valores o alguna administradora de fondos de pensiones (AFP) y, al igual que esta, pretendía resguardar y proteger el mercado y los intereses colectivos de los inversores y del público general. ${ }^{76}$ En efecto, a diferencia de la Ley $\mathrm{N}^{\circ} 18.045$ original del año 1981, en esta modificación se señalaba que el uso de información privilegiada de sociedades anónimas y de las intenciones de transacción de Fondos de Pensiones o de Fondos de Inversión, o la manipulación de los precios de mercado con recursos propios y de terceros, constituirían prácticas que reducen la confianza en la equidad del sistema, factor que inhibiría su profundización y masificación. ${ }^{77} \mathrm{Su}$ fundamentación específica se relaciona con la asimetría informativa existente entre los emisores (en un primer grado) y los intermediarios de valores e inversionistas institucionales (en un segundo grado) que disponen, respecto de los mismos y de sus valores, de una cantidad de información superior a cualquier otro agente económico. Estas normas buscarían inhibir, a través de la regulación, que los primeros niveles pudieran aprovecharse de dicha asimetría revelando o utilizando dicha información durante el tiempo en que esta aún no es divulgada oficialmente al mercado. Con ello se evitaría la discriminación en el conocimiento de la información y se cumpliría el objetivo de una participación igualitaria de oportunidad en la información, por un lado, y por otro, de dar una mayor confianza al inversionista en general. En relación a este último punto, se destaca, que es la principal característica de los mercados de valores la búsqueda constante de la protección de la fe pública. ${ }^{78}$

Coherente con los aspectos anteriormente mencionados, el legislador elimina la sanción de devolver a la caja social el monto obtenido como ventaja ya que, como fundamenta el Superintendente de Valores en su defensa del proyecto en el Congreso Nacional:

"en la mayor parte de los casos, no es la caja social la que se ve perjudicada por el uso de información privilegiada $y$, en consecuencia, no es dable establecer el beneficio de indemnización para esa caja social." ${ }^{, 79}$

Con el objetivo de no perpetuar equívocos $-\mathrm{y}$ destacar equivocaciones- es necesario recalcar que si bien esta decisión es coherente con el modelo de protección institucional y está presente tanto en los discursos de los defensores del proyecto (Superintendente y Gobierno) como de los legisladores, se mantiene la idea de vincular sus pilares fundamentales con modelos del derecho comparado -en especial al modelo

enero de 1994, Legislatura $327^{\text {a }}$ Extraordinaria, pp. 59; RIED UNDURRAGA, "Fundamentos de la Prohibición”, cit. nota ${ }^{\circ} 2$, pp. $441-442$.

${ }^{76}$ Véase la intervención de la Senadora Olga Feliú, en: Acta Sesión 22 2 de 11 de enero de 1994, Legislatura $327^{\text {a }}$ Extraordinaria, p. 68.

${ }^{77}$ Véase la intervención del Sr. Ministro de Hacienda Alejandro Foxley, en Actas de Formación de la Ley 19.301 de 1994, Sesión del Senado 15 Octubre de 1993, Legislatura 327a, Extraordinaria, pp. 20 - 21; Sesión $22^{\mathrm{a}}$, en 11 de enero de 1994, Legislatura $327^{\mathrm{a}}$, Extraordinaria, p. 14

${ }^{78}$ Intervención Superintendente de Valores y Seguros, en Actas de Formación de la Ley 19.301 de 1994, Sesión del Senado 15 Octubre de 1993, Legislatura 327 , Extraordinaria, p. 98.

${ }^{79}$ Intervención Superintendente de Valores y Seguros, en Actas de Formación de la Ley 19.301 de 1994, Sesión del Senado 15 Octubre de 1993, Legislatura 327 ${ }^{\text {a }}$, Extraordinaria, p. 54. 
Polít. crim. Vol. 8, № 15 (Julio 2013), Art. 2, pp. 23 - 63.

[http://www.politicacriminal.cl/Vol_08/n_15/Vol8N15A2.pdf]

estadounidense-, que en poco o nada se asimilaba en fundamentación y razones de la prohibición nacional. $^{80}$

Como ya se ha dicho, los problemas derivados de los conflictos de interés y asimetrías informativas, encontraron soluciones tanto preventivas como sancionadoras. Las primeras consistieron en la creación de normas de conductas referidas a incompatibilidades e inhabilidades. ${ }^{81} \mathrm{Al}$ mismo tiempo, se incorporaron prohibiciones directas y normas de sanción administrativas y penales. Mientras el sistema normativo comprendía -al principio del capítulo- una definición de Información privilegiada (art. 164), ${ }^{82}$ deberes de reserva y prohibiciones al uso y comunicación de información (art. 165) así como presunciones sobre conocimiento de dicha información (art. 166), los tipos infraccionales y penales se limitaban a sancionar sólo los niveles más altos de conocimiento objetivo de información, lo que en todo caso seguía coincidiendo con sujetos que mantenían con el emisor relaciones fiduciarias. La limitación del círculo de sujetos activos de las normas penales convertía a estas figuras prácticamente en delitos de infracción de deber, ya que coincidían adicionalmente con el círculo de destinatarios de los deberes positivos de entrega, reserva y administración de la información. ${ }^{83}$

En consecuencia, queda claro que -a diferencia de los señalado por parte de la doctrina- en esta segunda fase de modernización del mercado de valores, conductas como el uso de información privilegiada o la manipulación de precios del mercado obedecen a un modelo de protección institucional que, como señaló el Ministro de Hacienda de la época en su exposición de motivos al Congreso Nacional, desvalora dichas conductas en tanto constituyen prácticas que reducen la confianza en la equidad del sistema, factor que inhibiría su profundización y masificación. ${ }^{84}$ De la misma forma lo argumenta el Diputado informante del proyecto, al señalar que el sistema funciona sobre la base de la confianza en los instrumentos que el sistema ofrece, "en que no hay manejos raros, hay transparencia y todos los elementos indispensables para que el mercado funcione de manera adecuada". ${ }^{85}$ Así mismo, la literatura señala que "El buen funcionamiento del mercado de valores depende en gran medida en la confianza que inspire a los inversores." ${ }^{\text {" }}$

\footnotetext{
${ }^{80}$ Véase RIED UNDURRAGA, "Fundamentos de la Prohibición", cit. nota n 2, pp. 452 - 454 y pp. 462 - 463.

${ }^{81}$ Véase en extenso en SALAH ABUSLEME, Responsabilidad por uso de Información Privilegiada, cit. nota $\mathrm{n}^{\circ} 2$, pp. $151-171$ en relación a las medidas preventivas.

${ }^{82}$ Art. 164 señalaba que para los efectos de esta ley, el concepto de información privilegiada, se entiende como cualquier información referida a uno o varios emisores de valores, a sus negocios o a uno o varios valores por ellos emitidos, no divulgada al mercado y cuyo conocimiento, por su naturaleza, sea capaz de influir en la cotización de los valores emitidos y la información sobre las operaciones de adquisición o enajenación por realizar por un inversionista institucional en el mercado de valores, como también la información reservada a que se refiere el artículo 10 de esta ley.

${ }^{83}$ ROSAS, "El Delito de Abuso de Información Privilegiada", cit. nota n 2, pp. 16 - 18.

${ }^{84}$ Intervención del Sr. Ministro de Hacienda Alejandro Foxley, en Actas de Formación de la Ley 19.301 de 1994 en Sesión del Senado 15 Octubre de 1993, Legislatura 327ª, Extraordinaria, S. 20 y 21; Sesión 22a de 11 de enero de 1994, Legislatura 327 , Extraordinaria, p. 14

${ }^{85}$ Intervención del diputado informante Claudio Huepe, en Acta Sesión 8 de Junio de 1993; véase en: RIED UNDURRAGA, "Fundamentos de la Prohibición", cit. nota n², p. 449.

${ }^{86}$ CANALES, Información Privilegiada en la Ley del Mercado de Valores, cit. nota n ${ }^{\circ}$ 2, p. 2.
} 
GARCÍA PALOMINOS, Gonzalo. "Modelo de protección en normas administrativas y penales que regulan el abuso de Información Privilegiada en la legislación chilena".

Una tercera fase del programa de modernización y profundización del mercado de capitales chileno -y con ello una tercera fase de las sanciones al abuso de información privilegiadase inició con la promulgación de la ley 19.705 de 2000 y, últimamente, concretada con la Ley $\mathrm{N}^{\circ} 20.382$ de 2009. Con la Ley $\mathrm{N}^{\circ} 19.705$ de 2000, según señalaba el mensaje del Presidente de la República, se perseguía implementar medidas tales como la ampliación de la criminalización del abuso de información privilegiada, de manera de crear un mercado más eficiente, sano, competitivo, transparente y estable y con las necesarias regulaciones que posibilitaran, de ese modo, un desarrollo equilibrado y beneficioso para el país. ${ }^{87}$ Los principios que informaban esta reforma eran la protección a los accionistas minoritarios, la transparencia de la información (debido a la existencia de asimetrías de información entre los grupos controladores, accionistas externos y el mercado) y el trato igualitario entre accionistas. ${ }^{88}$ A diferencia del proyecto concretado en la Ley 19. 301 de 1994 (segunda fase), en este caso el proyecto estuvo contextualizado en la necesidad de regular el mercado general frente a comportamientos negativos de los grupos controladores contra los intereses de los inversores en general y los accionistas minoritarios, en particular. En relación al establecimiento de sanciones, se plateó la idea de ampliar la tipificación de conductas ilícitas que no recibían una sanción penal y que, por su gravedad, requerirían ser elevadas a la categoría de delitos, así como perfeccionar y mejorar algunas conductas relacionadas con información privilegiada. Según se señalaba confusamente en el Mensaje Presidencial, se pretendía ampliar las presunciones de posesión de información privilegiada (art. 166), ampliar las conductas de abuso de información privilegiada a la entrega o divulgación de Información Privilegiada y ampliar el círculo de autores del Art. 60 LMV más allá de los insider primarios e institucionales del Art. 166 LMV, así como otros delitos. Se trató, por lo tanto, de atacar la proliferación de conductas reñidas con las sanas prácticas mercantiles por parte de algunos intermediarios de valores, como por ejemplo el uso sin autorización de valores entregados en custodia por sus clientes, causando grave daño patrimonial a estos últimos, con el inconveniente de afectar gravemente la "fe pública y la confianza de los inversionistas". 89

La Ley 20.382 de 2009, por su parte, al igual que la anterior, busca aumentar el flujo de información al mercado, permitiendo a los inversores, a los accionistas y a la SVS una mejor supervisión y evaluación de la empresa emisora. Paralelo a lo anterior, se hace un esfuerzo por implementar mecanismos que aseguren y garanticen mayores grados de simetría de la información y fortalecimiento de los derechos de los accionistas minoritarios. ${ }^{90}$ En materia de información privilegiada, se modifican algunas prohibiciones administrativas que tienen incidencia directa en los tipos penales. ${ }^{91}$ Aun cuando se modifica el art. 165 LMV y, con ello, parte importante del objeto de análisis, no es posible identificar

\footnotetext{
${ }^{87}$ Mensaje del Presidente de la República, Título IV. 4., pp. 1 - 2.

${ }^{88}$ Mensaje del Presidente de la República, Título IV. 4.4., pp. 3 - 4.

${ }^{89}$ Mensaje del Presidente de la República, Título IV. 4.4., p. 5.

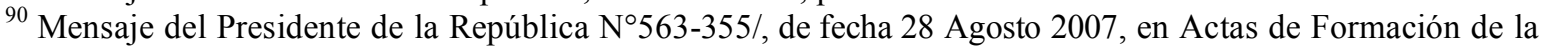
Ley 20.382 de 2009, Biblioteca Congreso Nacional. http://recursoslegales.bcn.cl/jspuirl/bitstream/10221.3/3860/2/HL20382.pdf

${ }_{91} \mathrm{Al}$ respecto véase VÁSQUEZ PALMA, "Revisión del ámbito de aplicación subjetivo", cit. nota n², pp. 249 - 252.
} 
Polít. crim. Vol. 8, № 15 (Julio 2013), Art. 2, pp. 23 - 63.

[http://www.politicacriminal.cl/Vol_08/n_15/Vol8N15A2.pdf]

una finalidad real de limitar el círculo de autores ni menos que esta responda a un cambio de orientación del legislador, cuestión que será analizado más abajo.

Se puede concluir que la actual etapa argumentativa se caracteriza por la superación -si es que alguna vez existió- del modelo orientado a la protección de la propiedad en la información de la empresa emisora y la configuración del injusto en el quebrantamiento de la relación fiduciaria o de confianza entre en el emitente y otra persona. Por el contrario, el modelo propuesto, al menos en rasgos generales, se orienta a la protección de los intereses colectivos de los participantes en mercado, ya sea en el funcionamiento eficiente del mercado, la confianza o fe pública en ciertas condiciones de funcionamiento del mismo.

\section{Estructura y sistemática normativa.}

Sin rechazar de plano la utilidad de la perspectiva histórica -que por cierto ayuda a entender la orientación político criminal, la estructura normativa o las distintas visiones sobre la configuración de los mercados de valores que orientan las perspectivas del legislador- sin embargo, resulta ser más provechoso el análisis de los elementos de la estructura normativa ya que no sólo constituyen un límite importante para el intérprete sino, por sobre todo, el objeto de la interpretación. Esta cuestión no ha sido siempre tenida en cuenta por la literatura. Por lo anterior, adicional a la perspectiva histórica, aquí se propone un análisis de los elementos de la estructura normativa de manera de verificar desde el contenido de las normas que regulan el abuso de información privilegiada, a qué modelo responde su contenido. En especial, se tendrá en consideración los siguientes elementos: el concepto de valor o instrumentos financiero (objeto de la acción), los mercados abarcados por el ámbito de aplicación de la norma, el concepto de información y el círculo de destinatarios de la norma en relación también con el círculo de autores de los tipos penales.

a) La actual regulación chilena de abuso de información privilegiada no desarrolla un concepto especial -como sí lo hace, por ejemplo, la ley alemana con el concepto "Insiderpapier" de información privilegiada. Así, por ejemplo, en el caso alemán el $\S^{\circ} 12$ (WpHG) le otorga al concepto Insiderpapier ser el elemento que determina -junto al concepto de Insiderinformation (equivalente funcional de nuestra información privilegiada) - el ámbito de aplicación objetiva de la norma. Este, por ejemplo, se configura sobre la base de dos elementos: La naturaleza del instrumento financiero y el mercado de referencia, posibilitando determinar los ámbitos específicos en que la prohibición tiene sentido y descartando aquellas en que las finalidades de la regulación y protección dejan de ser validas y necesarias. El primer elemento abarca expresamente determinados instrumentos financieros y las condiciones para ser abarcados, mientras que el segundo el mercado específico en que dichos instrumentos son transados. De esta forma, sólo son abarcados por el ámbito de aplicación de la norma un grupo limitado de instrumentos financieros -

92 Por todos ZIOUVAS, Das neue Kapitalmarktstrafrecht, cit. nota $\mathrm{n}^{\circ}$ 41, p. 60; DOUKLIAS, Der börsenorientierte Anlageschütz, cit. nota $\mathrm{n}^{\circ} 41$, p. 115; SETHE, “§ $12 \mathrm{WpHG}$ Insiderrecht” cit. nota $n^{\circ} 10$, Rn. 14. 
GARCÍA PALOMINOS, Gonzalo. "Modelo de protección en normas administrativas y penales que regulan el abuso de Información Privilegiada en la legislación chilena".

aquellos que son objeto de las transacciones e interrelaciones anónimas y en que entre emisor e inversor existe dependencia informativa-y sólo en la medida que la interacción se produzca en mercados de valores o plataformas (ej. bolsas de comercio) reguladas, medianamente regulados y supervigilados ya sea por la Bundesanstalt für Finanzdienstleistungsaufsicht o Bafin (equivalente funcional de la SVS) o la Börsenaufsichtsbehörden o BAD (institución pública que supervigila el funcionamiento de las Bolsas de comercio), ya que son los únicos que pueden asegurar o garantizar altos niveles de transparencia, formación regulada de precios y acceso igualitario a la información y, por lo mismo, los únicos respecto de los cuales se puede hablar de correcto funcionamiento de un sistema $^{93}$ o de confianza en igualdad de acceso a la información. ${ }^{94}$

Tanto los tipos administrativos que resultan de la relación entre el art. 58 y 165 y siguientes y penales chilenos del art. 60 letra e), g) y h) LMV y Art. 159 D.L. 3.500, ${ }^{95}$ en cambio, describen el objeto de la acción desde el concepto genérico "Valores de Oferta Pública", sin aportar características especiales que permitan determinar mercados o submercados específicos y, por lo mismo, fijan un ámbito de aplicación más extenso que el definido por el modelo de protección patrimonial. Esto porque dicho concepto coincide con el objeto utilizado por la Ley $\mathrm{N}^{\circ} 18.045$ para fijar su ámbito de aplicación general en el art. $1 \mathrm{LMV}$. La definición de dicho concepto "valores de oferta pública" no está, sin embargo, establecida en la Ley $\mathrm{N}^{\circ} 18.045$ que regula el mercado de valores, ni de manera conceptual ni enumerativa. Sólo define, por separado, lo que se entiende por "Valores" (art. 3 LMV) y, por otro lado, lo que se entiende por "Oferta Pública" (art. 4 LMV). De ambos concepto es posible extraer consecuencias sistemáticas. El objeto de la acción del abuso de información privilegiada -a diferencia de las características del modelo norteamericano- abarcaría valores transados en submercados tan variados como el mercado de capitales, mercado de bonos, derivados, debentures, de cuotas de fondo mutuos, de planes de ahorro, de efectos de comercio y, en general, de todo título de crédito o inversión. ${ }^{96}$ Los objetos de acción abarcados, tanto por el ámbito de aplicación de la ley $\mathrm{N}^{\circ} 18.045$ como por el ámbito de aplicación de las normas específicas, dan cuenta de mercados diversos no limitados al llamado mercado de capitales en sentido estricto (que se caracteriza por la estructura: empresa emisora/ títulos representativos de su valor/inversor), lo que da cuenta de tratarse de una protección amplia a diversos ámbitos de interrelación comercial que no se limitan a las caracterizadas por la interdependencia informativa entre emisor e inversor ni menos por las meras relaciones fiduciarias entre emisor y el tenedor de información. ${ }^{97}$

\footnotetext{
${ }^{93}$ SETHE, “\$ 12 WpHG Insiderrecht”, cit. nota $n^{\circ} 10$, Nm. 14.

${ }^{94}$ WEBER, Andreas, "Das neue deutsche Insiderrecht", Betriebs-Berater (BB), Vol. 4, 1995, p. 164.

${ }^{95}$ El artículo Art. 60 LMV establece cuatro ilícitos penales. Los tres primeros ilícitos - letras e), g) y h) - se refieren a usar o revelar deliberadamente "información privilegiada", cuando se trate de transacciones u operaciones sobre "valores de oferta pública", mientras que el ilícito penal de la letra d) se refiere a la revelación de información reservada en razón de su cargo o posición en las sociedades clasificadoras.

96 Sobre el concepto de "valor" ver TRUCCO, Eduardo, Las Bolsas de Valores y su Reglamentación, Santiago: Editorial Jurídica Ediar - ConoSur, 1989, pp. 7 - 8; JARA AMIGO, Rony, "Oferta pública y privada de valores en el mercado norteamericano: Una visión comparada”, Revista Chilena de Derecho: Vol. $28, \mathrm{~N}^{\circ} 1,2001$, p. 95.

${ }^{97}$ Aunque, como ya lo hemos señalado, la sentencia de la I. Corte de Apelaciones en Causa Rol $\mathrm{N}^{\circ} \mathrm{Criminal}$ 992-2010 (Caso Inverlink), de fecha veintidós de noviembre de dos mil once, representa un exceso en la
} 
Polít. crim. Vol. 8, № 15 (Julio 2013), Art. 2, pp. 23 - 63.

[http://www.politicacriminal.cl/Vol_08/n_15/Vol8N15A2.pdf]

b) El concepto de información privilegiada, por su parte, también ha sufrido importantes modificaciones que dan cuenta de la cristalización del modelo de protección institucional del mercado de valores en desmedro de otros posibles modelos de protección. ${ }^{98}$ Dicho concepto responde, en efecto, al modelo europeo que caracteriza a la información "objeto de abuso" desde la perspectiva de la necesidades racionales de inversor y, en caso alguno, desde la perspectiva de la propiedad o valor patrimonial de la misma para el emisor. Se trata de un modelo ideal de información mínima para la decisión del inversor -desde un parámetro de inversor racional $^{99}$ - pero que tiene la relevancia no sólo de ser esencial y, por lo mismo, condición mínima para una decisión individual, sino que es condición para una correcta formación de precios. Aquí, sólo analizaremos dos aspectos que nos ayudarán a probar la opción del legislador por el modelo institucional: su referencia a uno o varios emisores de valores, a sus negocios o a uno o varios valores por ellos emitidos y la capacidad de influir en la cotización de los valores emitidos.

En efecto, la definición de "Información Privilegiada"100 pasó a abarcar como objeto de información, no sólo informaciones referidas a "emisores de valores", 101 sino también informaciones referidas a los negocios de los emisores o a uno o varios valores emitidos por ellos. Se trata, por lo tanto, de informaciones que traspasan el ámbito de la propiedad del emisor y que abarcan informaciones importantes para el mercado del valor -market informations o informaciones del mercado- pero que pueden incluso llegar a ser de interés público como una sentencia judicial o la información proveniente de un ente regulador. En otras palabras, se podría tratar de información de otros sujetos o sobre hechos externos al emisor, pero siempre que se relacione directamente con el emisor o que afecte al valor por

interpretación del ámbito de aplicación de la ley, sin embargo, es un buen ejemplo de de interpretación del concepto amplio ya que en su considerando $6^{\circ}$ señala "Que, acto continuo, la información privilegiada que se revele debe ser referida a "uno o varios emisores de valores" y, en la especie, el Banco Central de Chile, conforme a lo dispuesto por la Ley $\mathrm{N}^{\circ} 18.840$, Orgánica Constitucional del Banco Central, en sus artículos 28 y $34 \mathrm{~N}^{\circ} 1,5$ y 6 , dicho organismo tiene el carácter de sujeto emisor en el mercado de valores, sin perjuicio que se excluya la aplicación a su respecto la Ley $\mathrm{N}^{\circ} 18.045$, de acuerdo al artículo 3 inciso 2, a los valores por él emitidos, por cuanto dicha exclusión sólo se refiere al régimen jurídico que regula dichos valores pero no de la sujeción a la Ley de Mercado de Valores en la calidad referida. Finalmente, la información privilegiada que se revele puede ser referida "a sus negocios" (de los emisores), siendo "negocio" del Banco Central, entre otros, fijar las tasas de interés."

${ }^{98}$ Un completo análisis de los elementos de la definición legal véase en VÁSQUEZ PALMA, "Revisión del ámbito de aplicación subjetivo", cit. nota n ${ }^{\circ} 2$, pp. $252-268$.

${ }^{99}$ Sobre el origen del criterio del inversor racional, véase SEMINARA, Sergio, "Kapitalmarktinformationen und Strafrecht in rechtsvergleichender Sicht", SIEBER, Ulrich (Ed.), Festschrift für Klaus Tiedemann zum 70 Geburtstag, Köln: Carl Heymanns Verlag, 2008, p. 1089.

100 En efecto, el concepto de "información privilegiada" está establecida en el art. 164 LMV y es consecuencia de la modificación introducida por la Ley $\mathrm{N}^{\circ}$. 19. 301 de 1994. Dicho artículo define esta información como "cualquier información referida a uno o varios emisores de valores, a sus negocios o a uno o varios valores por ellos emitidos, no divulgada al mercado y cuyo conocimiento, por su naturaleza, sea capaz de influir en la cotización de los valores emitidos."; sobre las modificaciones posteriores y evolución véase VÁSQUEZ PALMA, "Revisión del ámbito de aplicación subjetivo", cit. nota nº 2, pp. $252-268$.

${ }^{101}$ Ver PRADO PUGA, "Acerca del concepto de Información Privilegiada", cit. nota n ${ }^{\circ}$ 2, p. 245; Comité de Regulación y Autoregulación de la Bolsa de Comercio de Santiago, Reglas para prevenir y combatir el Uso de Información Privilegiada y la Manipulación de Mercado, Santiago. 2009, p. 4. 
GARCÍA PALOMINOS, Gonzalo. "Modelo de protección en normas administrativas y penales que regulan el abuso de Información Privilegiada en la legislación chilena".

él emitido. ${ }^{102}$ Al mismo tiempo, la definición abarca bajo el concepto de "negocios del emitente", tanto las informaciones relativas a hechos internos del ente emisor como a hechos o informaciones externas al mismo, incluso aquellos relacionados indirectamente con el emisor y sus negocios. Una opinión en ese sentido, es aquella que señala que debe entenderse incluida dentro de la información referida a un emisor o a sus negocios, la información que dice relación con sus filiales, matrices o empresas de grupo al que pertenece, en la medida que sea relevante para el respectivo emisor. ${ }^{103}$ Estas informaciones comprenderían, por ejemplo, el conocimiento acerca del cambio de control de un emisor, conocimiento de las dificultades extremas para el aprovisionamiento de un insumo esencial para la operación ordinaria, conocimiento de una contingencia tributaria que generará una gran pérdida en la matriz o en una filial de un emisor, etc. ${ }^{104}$ En todo caso, esta opinión principalmente representada por los Comités de Regulación y Autorregulación de la Bolsa de Valores de Santiago- agrega como ejemplo, la información no relacionada directamente con los negocios del emitente, pero que pueden tener efectos en sus negocios y, por tanto, en los valores emitidos por éste. Así, ejemplifica como información privilegiada la "inundación de la principal planta productiva de una empresa cuyas acciones se transan en bolsa", si es un hecho no conocido y los efectos de esa inundación no han sido debidamente informados. ${ }^{105}$ Adicionalmente, el concepto abarca dos objetos de información que no siguen lógicas diversas a las establecidas en la definición del inc. 1 del art. 164, como pretende argumentar Vásquez Palma, sino que simplemente se someten a un régimen especial relativa a la prueba de su relevancia ${ }^{106}$ o una especie de presunción de la capacidad de influir en el valor. ${ }^{107}$ Se trata tanto de la información reservada -que por su naturaleza,

${ }^{102}$ De esta opinión ROSAS, "El Delito de Abuso de Información Privilegiada", cit. nota n 2, p. 13; Comité de Regulación y Autoregulación de la Bolsa de Comercio de Santiago, Reglas para prevenir y combatir el Uso de Información Privilegiada y la Manipulación de Mercado, Santiago. 2009, p. 4.

${ }^{103}$ PRADO PUGA, "Acerca del concepto de Información Privilegiada", cit. nota ${ }^{\circ} 2$ 2, p. 245; Comité de Regulación y Autoregulación de la Bolsa de Comercio de Santiago, Reglas para prevenir y combatir el Uso de Información Privilegiada y la Manipulación de Mercado, Santiago. 2009, p. 4.

${ }^{104}$ Comité de Regulación y Autorregulación de la Bolsa de Comercio de Santiago, Reglas para prevenir y combatir el Uso de Información Privilegiada y la Manipulación de Mercado, Santiago. 2009, p. 4.

${ }^{105}$ Comité de Regulación y Autorregulación de la Bolsa de Comercio de Santiago, Reglas para prevenir y combatir el Uso de Información Privilegiada y la Manipulación de Mercado, Santiago. 2009, S. 4

${ }^{106}$ VÁSQUEZ PALMA, "Revisión del ámbito de aplicación subjetivo", cit. nota n² 2, pp. $275-276$.

${ }^{107}$ La extensión a este tipo de información no constituye ninguna novedad y es tenido, por gran parte de la literatura, como una ejemplificación o tipo de información privilegiada "per se". En efecto, PFEFFER ["Concepto de información privilegiada", cit. nota $n^{\circ} 2$, pp. 167 - 168] señala, en relación a la información reservada, que la calificación "per se" de este tipo de información como privilegiada radica en una doble razón. Primero, y la más importante, porque no es pública y coloca en situación de privilegio y ventaja a quien la conoce. Segundo, porque se trata de información sensible y relevante que tiene un potencial para influir la cotización de los valores en el mercado, desde el momento que se trata de información referida a negociaciones aún pendientes. Al mismo tiempo, señala, que al tratarse esta información de un tipo especifico de información privilegiada, existe una especie de presunción acerca de su aptitud causal para afectar el precio y la cotización del valor en el mercado. Esto significa que para configurar la infracción de los deberes de conducta asociados a quienes conocen información reservada- como un tipo especifico de información privilegiada- basta con probar la existencia del acuerdo de directorio que le dio carácter de reservada a cierta información y la transacción con valores referidos a tal información. Ello será suficiente para estar en presencia de este tipo específico de información privilegiada. Según PFEFFER ["Concepto de información privilegiada”, cit. nota ${ }^{\circ} 2$, p. 168] y GUZMÁN ANRIQUE [Información Privilegiada, cit. nota ${ }^{\circ} 2$, p. 56.], en relación a los inversores institucionales, se consagra aquí una suerte de presunción sobre el impacto que las 
Polít. crim. Vol. 8, № 15 (Julio 2013), Art. 2, pp. 23 - 63.

[http://www.politicacriminal.cl/Vol_08/n_15/Vol8N15A2.pdf]

se trata de información interna del emisor-e información relativa a inversiones futuras de inversores institucionales que, por naturaleza, constituye información externa al emisor. En consecuencia, si bien existe una ampliación del objeto de información más allá de lo referido al propio emisor -entendiéndose por tal un rechazo al modelo norteamericanoincluso a información de mercado, ${ }^{108}$ sin embargo, como bien lo capta Vásquez Palma, no se explican las razones para limitar sólo a los tres factores contenidos en la definición del art. $164 \mathrm{LMV}$, si el modelo al cual responde, permite una protección aún más amplia.

Otro aspecto del concepto de "información privilegiada" que entrega pistas en relación al modelo de protección desarrollado por el legislador es el relativo a su "capacidad para influir en el precio del valor de oferta pública" (art. 164). Este elemento, ya clásico en los modelos orientados a la protección de los inversores y del inversor racional -a diferencia del modelo estadounidense en que se presenta accidental y esporádicamente- ${ }^{109}$, es esencial en el modelo europeo, ${ }^{110}$ y presente, por ejemplo, tanto en la regulación alemana ( $\$ 13$ Abs. $1 \mathrm{WpHG}$ ) como española (Art. $285 \mathrm{CP}$ y art. 81.1 LMV). ${ }^{11}$ Se trata de una cláusula de relevancia de la información y que tiene el sentido de definir "ex ante" informativas esenciales - desde el parámetro del inversor racional ${ }^{113}$ - para una correcta decisión de inversión. Desde esa perspectiva, puede ser entendida como una información

operaciones de un inversionista institucional producen en el mercado. Por el sólo hecho de que un inversionista institucional opere en el mercado de valores se asume, por el legislador, de que tal operación tiene el potencial de afectar la cotización y precio de los valores. En este caso basta con el conocimiento que se tenga de la operación de adquisición o enajenación para estar en posesión de información privilegiada, ya que el potencial o aptitud de las operaciones del inversionista institucional para afectar el precio del valor está implícito en el concepto.

${ }^{108}$ En este sentido también BASCUÑÁN RODRÍGUEZ, “La regulación de la información privilegiada", cit. nota $\mathrm{n}^{\circ} 2$, pp. $95-96$.

109 Véase en la literatura chilena SALAH ABUSLEME, Responsabilidad por uso de Información Privilegiada, cit. nota ${ }^{\circ} 2$, pp. 14.

${ }^{110}$ Véase al respecto la Directiva 2003/6/ CE y el art. 1 de la Directiva 2003/124/CE.

111 Al respecto véase BAJO FERNÁNDEZ/BACIGALUPO, Derecho Penal Económico, cit. nota $\mathrm{n}^{\circ} 10$, p. 529

112 Véase el $\mathrm{N}^{\circ} 2$ del Art. 1 de la Directiva 2003/124/CE como manifestación de este modelo de determinación de la relevancia.

${ }^{113}$ El concepto de inversor racional es objeto de importantes discusiones en la dogmática alemana y que pueden dar luces a nuestro problema. El problema al que se enfrenta es que los inversores que participan en los mercados son muy variados y que van desde el inversor lego hasta inversores institucionales, inversores profesionales, corredores de bolsa, etc. y que tienen distintas expectativas informativas (SCHRÖDER, Christian, Handbuch Kapitalmarktstrafrecht, Capitulo 2, Köln, Editorial Carl Heymanns, 2007, Nm. 181). Parte de la literatura alemana y la jurisprudencia (véase SCHRÖDER [Handbuch Kapitalmarktstrafrecht, cit. nota $n^{\circ} 113, \mathrm{Nm}$. 183] distinguen entre el inversor racional y un corredor de bolsa (ASSMANN, HeinzDieter, "§13 WpHG”, en: ASSMANN/SCHNEIDER, Handbuch des Kapitalanlagerechts, 3" Edición, 2003, Nm. 65 - 66; CASPARI, Karl-Burkhard, "Die geplante Insiderregelung in der Praxis", Zeitschrift für Unternehmens- und Gesellschaftsrecht (ZGR), 1994, p. 540; la opinión contraria: [SETHE, "\$ 12 WpHG Insiderrecht", cit. nota $n^{\circ} 10, \mathrm{Nm} .48$ ], ya que estas normas estarían dirigidas al inversor medio. SCHRÖDER [Handbuch Kapitalmarktstrafrecht, cit. nota $\mathrm{n}^{\circ}$ 113, Nm. 182] intenta, sin embargo, destacar que los mercados abarcados por la regulación son variados, incluyendo algunos en que el inversor medio derechamente no participa. Por lo mismo, el concepto del inversor racional es más dinámico y debería adaptarse a cada mercado. Así, por ejemplo, los criterios e informaciones para la decisión del inversor en un mercado de renta será muy distintas al del mercado accionario. 
GARCÍA PALOMINOS, Gonzalo. "Modelo de protección en normas administrativas y penales que regulan el abuso de Información Privilegiada en la legislación chilena".

relevante para el inversor racional aquella que constituye un indicio del potencial de influencia del curso o el precio del valor ${ }^{14} \mathrm{o}$, a la inversa, como toda aquella información que por ser importante y tomada en cuenta por el inversor racional en sus decisiones y que, por lo mismo, normalmente afecta la cotización del valor. ${ }^{15}$ Tanto el modelo chileno como el europeo configuran el concepto de información privilegiada $o$, en el caso alemán, Insiderinformation -en el sentido de la teoría económica clásica- desde la orientación subjetiva de las expectativas de inversor racional y desde el análisis "ex ante" de la capacidad para influir en la cotización. En este mismo sentido, por ejemplo, Prado Puga para el derecho administrativo sancionador ${ }^{116}$ o Rosas para el derecho penal ${ }^{117}$, han sostenido que se trata de un examen de "idoneidad" que representa la importancia que un hombre razonable le asignaría anticipadamente a una información, conforme al paradigma establecido en el art. 9 inc. $2^{\circ}$ referido a la información esencial de la cual surgen deberes de información de los emisores a favor del ente regulador y del mercado. ${ }^{118}$ Para desvirtuar esta tesis, una parte de la doctrina chilena ha tenido que desestructurar los tipos infraccionales y penales que, configurados por el legislador como delitos de peligro abstracto (la conducta no representa una lesión para el bien jurídico) y tipos de mera actividad (no exigen un resultado), son forzados a ser interpretados de manera ad-hoc a la necesidad. Así, por ejemplo, Alcalde se ve obligado a sostener que dicha exigencia no sólo implica que los tribunales deben apreciar la aptitud o capacidad de influir en la cotización de un valor sobre la base de la realidad económica concreta (análisis ex ante), sino que además deben evaluar (ex post) si a la luz de los antecedentes particulares existió una relación de causa-efecto entre el conocimiento que se tuvo de tal información (causa) y la variación concreta del precio (efecto), en términos tales que tal variación resulte como consecuencia directa, inmediata y necesaria de dicho conocimiento (conditio sine qua non). ${ }^{119}$ Con esta doble exigencia "ex ante" y "ex post" -en todo caso incoherente con su punto de partida en el modelo norteamericano sostenido por el autor- se fuerza una mutación estructural desde la exigencia de una "mera actividad" a la exigencia de un "resultado" no requerido expresamente por las normas de sanción (tipo administrativo y penal). Esta interpretación, no sólo no puede ser aceptada desde la perspectiva del principio de legalidad y tipicidad (en relación a las normas penales), sino que además es inaplicable en relación a las normas de conducta, las que tienen como punto de partida la posibilidad que los destinatarios de la misma puedan, con seguridad, definir "ex ante" si una información es "privilegiada".

\footnotetext{
${ }^{114}$ Véase ZIOUVAS, Das neue Kapitalmarktstrafrecht, cit. nota n ${ }^{\circ} 41$, p. 232; ASSMANN, Heinz-Dieter, "Das künftige deutsche Insiderrecht (II)", en: $A G, 1994$, p. 242; en la literatura chilena, aunque de manera general, GASPAR/ARAYA, "Uso de Información Privilegiada", cit. nota n² 2, p. 282.

${ }^{115}$ Véase ASSMANN, "Das künftige deutsche Insiderrecht (II)", cit. nota n¹14, § 13, Nm. 62.

${ }^{116}$ PRADO PUGA, “Acerca del concepto de Información Privilegiada”, cit. nota n 2, pp. $245-246$.

${ }^{117}$ ROSAS, "El Delito de Abuso de Información Privilegiada", cit. nota ${ }^{\circ} 2$ 2, p. 14; siguiendo a este autor, ROSENBLUT, Verónica, "El denominado caso "Schwager": Análisis de histórica condena por uso de información privilegiada y manipulación bursátil”, Revista Jurídica del Ministerio Público N 46, marzo 2001, p. 197.

118 "Se entiende por información esencial aquella que un hombre juicioso consideraría importante para sus decisiones sobre inversión"

119 ALCALDE RODRÍGUEZ, "Uso de Información Privilegiada", cit. nota ${ }^{\circ}$ 2, pp.18 - 19; de manera asistemática con su punto de partida en el modelo institucional, sigue esta misma idea VÁSQUEZ PALMA, "Revisión del ámbito de aplicación subjetivo", cit. nota n² 2, p. 265.
} 
Polít. crim. Vol. 8, № 15 (Julio 2013), Art. 2, pp. 23 - 63.

[http://www.politicacriminal.cl/Vol_08/n_15/Vol8N15A2.pdf]

No es el momento para tratar en profundidad estas problemáticas, sin embargo, desde los objetivos aquí planteados es necesario destacar que cualquiera sea el camino que se emprenda es evidente que en el centro de la valoración están las expectativas de los inversores en la disposición de información necesaria para la decisión de una inversión y, por ello, con efectos directos en el funcionamiento del mercado. Así, si se agrega la interrogante sobre la relevancia de vulnerar las expectativas informativas para el bien jurídico - sea este la confianza en el mercado de valores o el correcto funcionamiento del mismo - se amplían aún más las posibilidades de análisis. Así, por ejemplo, para quienes entienden el bien jurídico como el correcto funcionamiento de la bolsa, ${ }^{120}$ se vinculará este elemento sólo con la capacidad de esta para influir en la correcta formación de precios de valores transados en "bolsa" (correcto funcionamiento de la Bolsa de Valores). Para quienes entienden que la confianza en el mercado de valores es el resultado del cumplimiento de deberes de información destacarán un dato ineludible: coinciden las exigencias de la información privilegiada con las cualidades de la información objeto de dichos deberes.

(d) Finalmente, el "círculo de destinatarios de la norma" fijado en el art. 165 LMV así como el "círculo de autores o sujetos activos" del delito (art. 60 LMV) nos dará luces acerca de esta nueva sistemática orientada al modelo de protección institucional. Se analizará desde la perspectiva del derecho penal, ya que esta permite, por una parte, abarcar tanto la problemática del círculo de destinatarios de las normas de conducta administrativas (art. 164 y 165 LMV), como específicamente los tipos infraccionales y penales, debido a su estrecha relación y, por otra, permite explicar la interrelación entre estas normas.

Los tipos penales de "abuso de Información Privilegiada" chilenos utilizan dos modelos de tipificación distintos para determinar el ámbito de aplicación personal (o círculo de autores) en los tipos penales. El primero es el llamado "modelo de listado", utilizado en el art. 159 D.L. 3.500 y la letra e) del art. 60 LMV, en virtud del cual el tipo penal o la norma a la que se remite el tipo penal enumeran taxativamente los sujetos que componen el círculo de autores. Así, mientras el art. 159 D.L. 3.500 enumera taxativamente a los sujetos que en razón de su cargo o posición tienen acceso a información privilegiada -como directores, gerentes, operadores de mesa de dinero, y trabajadores de una Administradora de Fondos de Pensiones (AFP)-, la letra e) del art. 60 LMV se remite al art. 166 LMV. $^{121}$ El segundo modelo es el denominado Modelo de "clausula general", al que responden las letras g) y h) del art. 60, y se caracteriza por utilizar la frase "El que" o "los que", refiriéndose al sujeto activo de una manera general y sin entregar criterios para su determinación.

\footnotetext{
${ }^{120}$ Véase, por ejemplo, GÓMEZ INIESTA, La utilización abusiva, cit. nota ${ }^{\circ} 10$, p. 256 y p. 291; FARALDO CABANA, Patricia, "Algunos aspectos del delito de uso de información reservada en el mercado de valores en el proyecto de Código Penal de 1994", Estudios Penales y Criminológicos, Univ. Santiago de Compostela, XVIII, 1995, pp. $56-58$.

${ }^{121}$ Art. 60 e) LMV "Las personas a que se refiere el artículo 166 que al efectuar transacciones u operaciones de valores de oferta pública, de cualquier naturaleza en el mercado de valores o en negociaciones privadas, para sí o para terceros, directa o indirectamente, usaren deliberadamente información privilegiada".
} 
GARCÍA PALOMINOS, Gonzalo. "Modelo de protección en normas administrativas y penales que regulan el abuso de Información Privilegiada en la legislación chilena".

Respecto del círculo de autores del tipo penal del art. 60 letra e), se puede constatar un cambio, aunque limitado, en la estructura y orientación de los tipos penales chilenos de "uso indebido de información privilegiada". Como ya se ha señalado, dicho tipo penal se remite al art. 166 LMV para definir su círculo de autores, precisamente norma que ha sido constantemente modificada y ampliada a lo largo de los años. Por lo mismo, y sin ser excesivamente amplio, cubre a sujetos sobre los que recaen deberes de entrega de información y de reserva de la misma, con excepción de algunos sujetos de las letras d), e) $\mathrm{y}$, en especial, la letra f) del Art. 166, por ejemplo, los cónyuges o convivientes de las personas señaladas en la letra a) del inciso primero, así como cualquier persona que habite en su mismo domicilio. Al mismo tiempo, se extiende hacia sujetos "externos" al emisor como los "inversionistas institucionales", pero que tienen un deber de resguardo de su información. ${ }^{122}$

Que estos sujetos internos y externos no agotan el círculo de autores, queda aún más claro si se analizan los tipos penales de las letras g) y h) del art. 60 que utilizan la técnica de la "cláusula general" con el objetivo de ampliar el círculo más allá de lo taxativamente estipulado por la figura del art. 60 letra e). Con el objeto de determinar dicho círculo de autores la doctrina y la jurisprudencia se ha diferenciado, según (i) considera que existen círculos determinados de destinatarios de las normas de conducta pre- o extrapenal ${ }^{123}$ o (ii) se trata de un círculo amplio que no merece mayores restricciones ${ }^{124} \mathrm{o}$, incluso, (iii) más amplio que el círculo de destinatarios de la norma de conducta administrativa (definido por el art. 165). ${ }^{125}$

Si se opta por la tercera alternativa (iii), el círculo de autores resulta ser amplio y sin mayores límites, lo que daría cuenta de una opción del legislador no sólo por el modelo de protección institucional, sino que además por desvincular el derecho extrapenal (privado) y el penal, con la consecuencia que se pasaría a abarcar constelaciones muy diversas, como la del delincuente que se aprovecha de la información que le proporciona un delito, de los iniciados sucesivos que no tienen ninguna relación con un iniciado primario o secundario, etc. $y$, en general, las normas de sanción penal podrían sancionar conductas de ámbitos no regulados por el derecho prepenal. Dicha opción debe ser, sin embargo, descartada porque no reconoce la relación de subsidiariedad y, por sobre todo, de accesoriedad del derecho penal económico con la regulación del ámbito extrapenal -que entiende que el derecho penal sólo sanciona los injustos más calificados de la regulación extrapenal, pero es accesoria y depende de esta- ni reconoce que la norma de conducta y los destinatarios de la misma, está fijado por esta última.

122 Un completo análisis véase en BASCUÑÁN RODRÍGUEZ, "La regulación de la información privilegiada", cit. nota ${ }^{\circ} 2$, pp. $99-102$

${ }^{123}$ BASCUÑÁN RODRÍGUEZ, "La regulación de la información privilegiada", cit. nota n 2, pp. 121 - 136; VÁSQUEZ PALMA, "Revisión del ámbito de aplicación subjetivo", cit. nota n 2, p. 276.

${ }^{124}$ Sentencia de la Corte Suprema en causa Rol N 4930-2004 de fecha 27 de Octubre de 2005 (Caso Banco de Chile) considerandos $21^{\circ}$ y $22^{\circ}$ en que se señaló que la ley no exige una vinculación directa entre la fuente de la información y el sujeto pasivo que accede a ella: "cualquier persona" puede ser sujeto activo del uso de información Privilegiada.

${ }^{125}$ SALAH ABUSLEME, Responsabilidad por uso de Información Privilegiada, cit. nota nº 2, pp. 218 - 219. 
Polít. crim. Vol. 8, № 15 (Julio 2013), Art. 2, pp. 23 - 63.

[http://www.politicacriminal.cl/Vol_08/n_15/Vol8N15A2.pdf]

Por el contrario, si se opta por la primera (i) o segunda alternativa (ii), en atención al reconocimiento de la accesoriedad, será necesario emprender un análisis de los destinatarios de las normas de conducta prepenales que regulan la posesión de información privilegiada, más concretamente de los artículos 165 y 166 LMV que, como ya se ha señalado, han sido objeto de modificaciones por la Ley $\mathrm{N}^{\circ} .19 .705$ de 2000 y por la Ley $\mathrm{N}^{\circ}$ 20. 382 de 2009. En efecto, el legislador ya señalaba en las discusiones de la Ley $\mathrm{N}^{\circ} 19.705$ de 2000, la necesidad de ampliar el círculo de sujetos activos en los demás tipos penales más allá de los sujetos nombrados en el Art. $166 \mathrm{LMV},{ }^{126}$ sin quedar limitada a ciertos sujetos en virtud de sus calidades, aunque manteniéndose dentro del marco establecido en el Art. 165 LMV. ${ }^{127}$ Esa idea expansionista ya plasmada en dicha modificación, aunque limitada por el art. 165 LMV, sin embargo, sufre una nueva modificación con la Ley 20. 382 de 2009 que reestructura la lógica del art. 165 LMV. Como claramente lo afirma Bascuñán Rodríguez esta ley cambia los presupuestos de los deberes y prohibiciones relativas a la información privilegiada que, hasta ese entonces, se refería a la tenencia $o$ tener acceso, cuestión que respondía a cierta lógica de las presunciones del art. 166 LMV. ${ }^{128}$ Actualmente, sin embargo, como bien constata este autor, el presupuesto para el surgimiento de deberes y prohibiciones dejó de ser el mero "acceso" a la información para pasar a ser la "posesión" de la misma, lo que debe entenderse en el sentido de "conocer la información", cuestión que podría obedecer a dos lógicas opuestas. La primera de ellas, en la lógica de los fundamentos del legislador, debería entenderse que el art. 165 abarca a cualquier persona que "en razón de su cargo, posición, actividad" o que además tenga "relación con el respectivo emisor de valores", posean por alguna razón información privilegiada. Bajo esta perspectiva, el cargo, posición o actividad sólo son situaciones referenciales, ya que lo relevante es la posesión de información privilegiada. Esta nueva norma no cambiaría mayormente lo ya establecido en el antiguo art. 165 LMV, ${ }^{129}$ con la sola excepción de la inexplicable limitación del concepto "relación" referido a emisores y sujetos nombrados en le art. 166 LMV. ${ }^{130}$ Así entendido, no sólo abarca a los llamados iniciados primarios o secundarios, e incluso a iniciados temporales, sino que además a externos que no mantienen una relación fiduciaria, posición o cargo en el ente emisor, pero que por su cargo, posición o actividad poseen o tienen conocimiento de la información

\footnotetext{
${ }^{126}$ Mensaje del Presidente de la República №153-339/, de fecha 30 Diciembre 1998, en Actas de Formación de la Ley $\mathrm{N}^{\circ} 19.705$ de 2000, p. 5; intervención del abogado Orlando Vásquez, de la Superintendencia de Valores y Seguros, en Actas de Formación de la Ley 19.705 de 2000, Informe Comisión de Hacienda, Boletín $\mathrm{N}^{\circ} 2.289$ - 05, pp. 31; véase al respecto SALAH ABUSLEME, Responsabilidad por uso de Información Privilegiada, cit. nota ${ }^{\circ}$ 2, p. 218.

${ }^{127}$ Intervención del abogado de la S.V.S. Orlando Vásquez, en Actas de Formación de la Ley 19.705 de 2000, Informe Comisión de Hacienda, Boletín N².289-05, p. 31.

${ }^{128}$ BASCUÑÁN RODRÍGUEZ, "La regulación de la información privilegiada", cit. nota n 2, pp. $102-109$.

${ }^{129}$ Artículo 165 inc. $1^{\circ}$ anterior a la modificación de la ley 20.382 de 2009 señalaba "Cualquier persona que en razón de su cargo, posición, actividad o relación tenga acceso a información privilegiada, deberá guardar estricta reserva y no podrá utilizarla en beneficio propio o ajeno, ni adquirir para sí o para terceros, directa o indirectamente, los valores sobre los cuales posea información privilegiada."

${ }^{130}$ Artículo 165 inc. $1^{\circ}$ actual señala "Cualquier persona que en razón de su cargo, posición, actividad o relación con el respectivo emisor de valores o con las personas señaladas en el artículo siguiente, posea información privilegiada, deberá guardar reserva y no podrá utilizarla en beneficio propio o ajeno, ni adquirir o enajenar, para sí o para terceros, directamente o a través de otras personas los valores sobre los cuales posea información privilegiada."
} 
GARCÍA PALOMINOS, Gonzalo. "Modelo de protección en normas administrativas y penales que regulan el abuso de Información Privilegiada en la legislación chilena".

privilegiada, como por ejemplo, el corredor de bolsa, el funcionario de una institución pública como un juez que dictará una sentencia que afectará el valor de un título de valor o la secretaria del Banco Central, etc. Al mismo tiempo, al igual que lo hace el art. 166 letras e) d) y f), este artículo en su inciso $1^{\circ}$ extiende el deber y la prohibición, a quienes tengan "relación" con las personas señaladas en el artículo siguiente, es decir, no sólo al inversor institucional y sus asesores, al funcionario de la SVS, o los cónyuges o convivientes de los directores, gerentes, administradores, ejecutivos principales y liquidadores del emisor o del inversionista institucional, sino que además a todo el que haya sostenido algún tipo de relación no sólo con estos insider institucionales, sino que además con cualquier otro sujeto de los nombrados en el art. 166 LMV.

Por el contrario, si se sigue la opción de entender en su sentido más restringido el art. 165 LMV, ${ }^{131}$ es decir, interpretando que tanto la posición, actividad o relación se refieren sólo al respectivo emisor de valores o a alguna de las personas señaladas en el artículo 166 LMV, cuestión que pude ser entendida como una manifestación más del modelo patrimonial orientado a la protección del emisor (modelo estadounidense), el ámbito de aplicación se reduce de manera relevante, al punto de limitar no sólo el círculo de destinatarios de la norma de conducta sino también el círculo de autores (el sujeto activo) sólo a iniciados (insider) relacionados con el emisor o algunos de los iniciados (insider) o externos (outsider) expresamente descritos en el art. 166 LMV. Una estructura como esta, daría cuenta de que los presupuestos del surgimiento de los deberes relacionados con la información privilegiada derivarían copulativamente tanto de la posesión de la misma (elemento meramente limitativo), como de la especial posición en que se encuentra el sujeto. Esta restricción, puede ser entendida en las limitaciones propias de las normas de sanción, pero no responde a la ratio legis y es absolutamente incompatible con los fines y deberes informativos que la normativa ha querido desarrollar.

En lo que nos interesa, sin embargo, cualquiera sea la interpretación -amplia o restrictivalo claro es que no es posible aceptar que el modelo que surge de la interpretación sistemático-normativa sea el modelo estadounidense o el modelo de la protección patrimonial del inversor individual (contrapartida anónima del insider). La estructura normativa es consecuencia de la coherente relación estructural existente entre las normas de conducta administrativa y las normas de sanción tanto administrativa como penal sobre abuso de información privilegiada. Por lo mismo, respecto del modelo estadounidense, concordamos con Bascuñán Rodríguez ${ }^{132}$ que agrega críticamente un aspecto injustificadamente omitido por los autores que proponen dicho modelo: Un modelo que asigna la propiedad de la información al emisor y que configura el injusto sólo en la relación fiduciaria sería incongruente con la existencia de los deberes legales de divulgación que pesan sobre los emisores de valores de oferta pública y que configuran los sistemas institucionalizados esenciales del mercado de valores chileno. ${ }^{133}$ Lo anterior

\footnotetext{
${ }^{131}$ Véase al respecto BASCUÑÁN RODRÍGUEZ, "La regulación de la información privilegiada", cit. nota n 2, pp. 105 - 108; VÁSQUEZ PALMA, "Revisión del ámbito de aplicación subjetivo", cit. nota nº 2, pp. 270 279.

${ }^{132}$ BASCUÑÁN RODRÍGUEZ, "La regulación de la información privilegiada", cit. nota n 2, pp. 90 - 91 .

${ }^{133}$ BASCUÑÁN RODRÍGUEZ, "La regulación de la información privilegiada", cit. nota ${ }^{\circ} 2$, p. 91.
} 
Polít. crim. Vol. 8, № 15 (Julio 2013), Art. 2, pp. 23 - 63.

[http://www.politicacriminal.cl/Vol_08/n_15/Vol8N15A2.pdf]

significa que dicha interpretación no considera que las normas de sanción no son autónomas, sino que responden a una institución -el mercado de valores- configurada normativamente por una serie de normas formales e informales que permiten la interrelación económica. Un sistema como el planteado por parte de esa doctrina, no considera dichos aspectos y desconoce la existencia de deberes informativos derivados del rol que se le asigna al derecho en la configuración y protección de dicho mercado.

La opción por el modelo de protección institucional y, en especial, por la confianza en la igualdad de oportunidades en el acceso a la información constituye el sentido teleológicovalorativo de la norma, interés que va más allá de los intereses societarios internos del emitente -modelo que, por lo demás, excluye del ámbito de aplicación de estas normas a todo el mercado de valores en sentido amplio (no referido al derecho societario)- o, por el contrario, más allá de los meros intereses patrimoniales del inversor. En todo caso, los intereses del emisor o fuente de la información, reciben una protección suficiente en los tipos penales de protección de secretos industriales (art. $284 \mathrm{CP}$ ) y públicos (Art. $246 \mathrm{CP}$ ) así como estos y los patrimoniales lo reciben también en sede civil. ${ }^{134}$

Lo anterior, sin embargo, sólo resuelve parte del problema administrativo sancionador, pero no el penal. Sin ser objetivo de este trabajo, sin embargo, es necesario destacar que la legitimación de la intervención penal en este ámbito aun está en juego. La amplitud del ámbito de aplicación, la falta de contornos claros, la falta de claridad y determinación del bien jurídico, siguen siendo problemas pendientes para esta rama del derecho. Por ahora, ya un avance es reconocer el modelo de protección.

\section{Conclusión y valoración final.}

a) En la literatura chilena sobre mercado de valores no es posible encontrar una opinión única sobre los modelos de protección que sirven de fundamento a las normas de conducta y de sanción sobre abuso de información privilegiada, produciéndose una constante tensión en la interpretación de las normas jurídicas. Si bien dicha tensión finalmente ha decantado en favor del modelo de protección institucional, probablemente por la influencia de la literatura europea, este se ha desarrollado asistemáticamente $\mathrm{y}$, en ocasiones, de manera ecléctica. Las razones dicen relación con que el modelo estadounidense propuesto por parte de la doctrina ha logrado imponer ciertas ideas que, recubiertas por una interpretación histórica, no hacen sino incorporar argumentos de lege ferenda en la interpretación del sistema normativo, pero que mirado desde una perspectiva global aparecen como asistemáticos y desvinculados de la configuración del mercado chileno.

En este trabajo, no sólo hemos demostrado lo anterior, sino que además hemos intentado probar tanto desde una revisión histórica como, por sobre todo, sistemático-normativa, que existe un modelo de protección diverso. En efecto, se ha demostrado que la Ley $\mathrm{N}^{\circ} 18.045$ no sólo en sus fundamentos experimentó una evolución significativa, sino que también se 134 Una opinión similar en STRATENWERTH, “Zum Straftatbestand des Missbrauchs von
Insiderinformationen”, cit. nota $n^{\circ} 41$, pp. $668-671$. 
GARCÍA PALOMINOS, Gonzalo. "Modelo de protección en normas administrativas y penales que regulan el abuso de Información Privilegiada en la legislación chilena".

manifestó en su estructura normativa que da cuenta de un modelo específico, aunque no siempre claro y coherente. El modelo chileno ha sufrido un cambió paulatino desde la reforma a la Ley $\mathrm{N}^{\circ} 18.045$ por la Ley $\mathrm{N}^{\circ} 19.301$ de 1994 y que ha quedado ampliamente demostrado y cristalizado en la nueva Ley $\mathrm{N}^{\circ} 20.382$ de 2009 que modificó parcialmente la prohibición. Este nuevo modelo se caracteriza, por un lado, por la ampliación tanto del ámbito de aplicación objetivo, en especial, de los conceptos de "valor de oferta pública" e "información privilegiada" así como en el ámbito de aplicación personal (círculo de destinatario de las normas de conducta así como los sujetos activos o círculo de autores de los tipos administrativos y penales).

b) El modelo de protección institucional, sin embargo, no es consecuencia de la sola interpretación sistemática de las normas de sanción administrativas o penales. Las normas de sanción aquí analizadas forman parte de una institucionalidad que no configura exclusivamente el mercado de valores chileno en cuanto tal, sino que responden a una necesidad de proteger dicha configuración y su capacidad de lograr fines. Dicho mercado, en efecto, se configura sobre la base de un número importante de normas de conducta y de sanción formales e informales que tienen por objeto orientar "el comportamiento individual de los inversores en sentido de posibilitar la participación en la determinada institución", para lo cual debe configurar un sistema que traiga orden en el quehacer cotidiano, reduciendo o impidiendo la incertidumbre que producen las relaciones humanas ${ }^{135}$ (a través de la eliminación de determinadas conductas) y, por lo mismo, elevando las posibilidades de interacción. ${ }^{136}$ En efecto, las instituciones económicas, como el mercado de valores, son entendidas como sistemas de "incentivo" constituidos por normas de interrelación, incluidas las encargadas de su realización. ${ }^{137}$ Por lo mismo, la opción por un modelo de protección u otro no depende únicamente de las pretensiones ideales del intérprete (lege ferenda), sino principalmente de la configuración real del mercado. Los modelos de protección individual del emisor (o modelos estadounidenses) o de protección individual del inversor (más bien cercana a la protección que puede brindar el derecho civil), evidencian desvinculación precisamente con la naturaleza y configuración del mercado de valores chileno.

Un ejemplo de dicha desvinculación, lo representa la incompatibilidad entre el propuesto modelo de protección individual al emisor -sobre la base de asignación de la propiedad de la información al emisor- con la configuración de subsistemas informativos que respondan a las expectativas propias de un sistema de dependencia informativa (emisor/inversor en el mercado primario y secundario) y que reducen la asimetría informativa entre unos y otros. La institucionalización del mercado de valores -desarrollada principalmente por la Ley $\mathrm{N}^{\circ}$ 18.045- introduce normas - mandatos, prohibiciones o permisiones- que, por un lado, ordenan una definida formación de subsistemas, mecanismos, unidades funcionales -por ejemplo, las plataformas de interacción como la Bolsa, sistemas de formación de precios o

\footnotetext{
135 RICHTER, Rudolf; FURUBOTN, Eirik, Neue Institutionenökonomik, Tübingen: $3^{\mathrm{a}}$ edición, Editorial Mohr Siebeck, 2003, p. 7.

${ }^{136}$ NORTH, Douglass, "Institutions", Journal of Economic Perspectives, vol. 5, N 1 (1991), p. 97.

${ }^{137}$ NEE, Victor; INGRAM, Paul, "Embeddedness and Beyond: Institutions, Exchange, and Social Structure", The New Institutionalism in Sociology, New York: Brinton, M. C./ Nee, V (Ed.), p. 19.
} 
Polít. crim. Vol. 8, Nº 15 (Julio 2013), Art. 2, pp. 23 - 63.

[http://www.politicacriminal.cl/Vol_08/n_15/Vol8N15A2.pdf]

sistemas informativos- y, por otro, los coordina, configurando este sistema de incentivo de interacciones económicas que le permiten funcionar eficazmente y alcanzar sus fines. ${ }^{138}$ Precisamente a esta configuración responden las normas que regulan y coordinan los subsistemas informativos y registrales tales como los regulados por medio de deberes informativos de los artículos 7, 17, 18, 20, 32, 43, etc. de la LMV o los deberes de registro como los exigidos en los art. 6 o 23 LMV. Un modelo, como el de la fiduciary duty theoryo misappropriation theory, al asignar la propiedad de la información al emisor, desconoce dicha configuración del mercado de valores $\mathrm{y}$, por lo mismo, la existencia de deberes $\mathrm{y}$ subsistemas basados en estos.

Las normas de sanción como las aquí analizadas, cumplen -en un modelo de protección institucional- la función de incentivar y proteger la capacidad de funcionamiento de dichos subsistemas (ejemplo, el de formación de precios) y, como consecuencia, son exitosos en la medida que logran su finalidad que, en este caso, a nivel macro, es asignar el capital y, a nivel micro, hacer funcionar los sistemas que buscan la confluencia o encuentro de oferta y demanda de participaciones o deuda de mediano o largo plazo. ${ }^{139}$

c) En las posiciones dogmáticas de la literatura chilena ya internas al modelo de protección institucional, sin embargo, se manifiestan tensiones en torno al modelo de entendimiento o comprensión del mercado de valores. Es posible evidenciar características del modelo neoclásico que, para efecto de la configuración del sistema, se basa en un modelo ideal de mercado de capitales eficiente, bajo el prisma del "inversor racional" 140 y que tenderá a configurar -ayudado de la regulación administrativa- sistemas y unidades funcionales que llenen las expectativas de dicho paradigma de la racionalidad (homo economicus) y en la idea que los inversores poseen un entendimiento del riesgo de sus decisiones y, por lo mismo, las expectativas normativas dicen relación con que su éxito es el resultado de su propio esfuerzo por lograr la maximización de la utilidad esperada. ${ }^{141}$ Por un lado, bajo esta idea se introducen normas de comportamiento que establecen importantes deberes de información, de inscripción en diferentes registros, principalmente a los emisores, y, al mismo tiempo, coordina dichos deberes con la implementación de sistemas de flujo información públicos y privados, supervigilancia privada (regulación de la auditoría externa de las empresas) y pública (SVS), etc., logrando mayor eficiencia informativa. ${ }^{142}$ Por otro, se intenta eliminar toda conducta que resulte distorsionadora o disfuncional para dicho

\footnotetext{
${ }^{138}$ PEETZ, Dietmar, Hedge-Fonds und Finanzmarktinstabilität, Universität Kassel, p. 90. (https://kobra.bibliothek.uni-kassel.de/handle/urn:nbn:de:hebis:34-2007011916704).

${ }^{139}$ LIEBEL, Hermann, Täter - Opfer - Interaktion bei Kapitalanlagebetrug, Neuwied: Editorial Luchterhand, 2002, p. 12.

${ }^{140}$ Véase RICHTER/FURUBOTN, Neue Institutionenökonomik, cit. nota $n^{\circ} 137$; PICOT, Arnold; DIETL, Helmut, "Informations(de-) regulierung am Kapitalmarkt aus institutionenökonomischer Sicht", en: SCHENK, E; SCHMIDTCHEN, D. (Ed.), Jahrbuch für neue politische Ökonomie, Neue politische Ökonomie der Regulierung, Deregulierung und Privatisierung. Vol. 13, Mohr, Tübingen, 1994, p.113; sobre los modelos de información véase FILIPIUK, Transparenz der Risikoberichterstattung, cit. nota $n^{\circ} 16, \mathrm{p} .76$.

${ }^{141}$ Véase FILIPIUK, Transparenz der Risikoberichterstattung, cit. nota ${ }^{\circ} 16, \mathrm{pp} .78-83$.

${ }^{142}$ FAMA, Eugene, "Efficient Capital Markets: A Review of Theory and Empirical Work", Journal of Finance, Vol. 25, (2), 1970, p. 387; FILIPIUK, Transparenz der Risikoberichterstattung, cit. nota $\mathrm{n}^{\circ} 16$, pp. $86-87$.
} 
GARCÍA PALOMINOS, Gonzalo. "Modelo de protección en normas administrativas y penales que regulan el abuso de Información Privilegiada en la legislación chilena".

sistema y que desincentive este modo de interacción, vale decir, principalmente aquellas conductas que vienen a impedir o distorsionar la eficiencia informativa. El uso de información privilegiada tendrá bajo este modelo un ámbito de aplicación más restringido y limitado a los deberes de información. De lo analizado en los elementos normativos presente en la Ley $\mathrm{N}^{\circ} 18.045$, parte importante de ellos se basan en este modelo.

El otro modelo en constante tensión es el modelo neoinstitucional que tiende a desmitificar la idea del inversor racional y pone el acento en los comportamientos y relaciones de los participantes en el mercado y entre estas y las normas de conducta y las expectativas de éstos en el mercado ${ }^{143} \mathrm{y}$, por lo mismo, esta teoría se concentra en las dificultades que resultan de la interacción humana y que se presentan como problemas de motivación y coordinación en un sistema configurado como "de incentivo". "B4 Bajo este modelo, la necesidad de configurar sistemas y la fundamentación de las normas de conductas y sanción sufren sino un cambio, al menos una ampliación relevante. Así, por ejemplo, la manipulación de mercado o de precios así como la presentación de información falsa, no son conductas solamente desvaloradas porque afectan el funcionamiento de un subsistema informativo importante, sino en razón de que afectan la necesaria confianza de los partícipes e inversores en ese mercado, cuestión relevante si se piensa en que un sistema poco confiable será abandonado por dichos inversores, perjudicando su liquidez. Así, por ejemplo, el uso de información privilegiada bajo el modelo de protección institucional encuentra en este modelo de mercado su principal fundamentación y es coherente con las opiniones y justificaciones del legislador chileno (aún cuando no necesariamente con los elementos normativos). Esto, porque la literatura ha demostrado que, en la realidad, las conductas de abuso de información privilegiada, desde el punto de vista de la efíciencia informativa, está lejos de ser un factor distorsionador para los sistemas de formación de precios, ya que, si bien influye en estos, incluso tiene la capacidad de reflejar una información no conocida rápidamente en los mismos. ${ }^{145}$ Por lo mismo, más bien la desvalorización dice relación con la capacidad de afectar las expectativas de igualdad de oportunidades o de acceso a la información de los inversores, cuestión que afectaría las funciones que se le asigna al mercado.

d) Avanzado con este trabajo un primer peldaño en el camino a la claridad conceptual (el modelo de protección), quedan pendiente aún cuestiones propias del modelo de protección institucional, como por ejemplo, cómo se compatibiliza la presencia de visiones distintas del mercado de valores - modelo neoclásico y neoinstitucional- en la regulación del abuso de información privilegiada. Al mismo tiempo, quedan pendientes problemas propios del derecho civil y del derecho penal. Para el primero, queda pendiente un análisis más

143 Ver RICHTER/FURUBOTN, Neue Institutionenökonomik, cit. nota $\mathrm{n}^{\circ} 137$; PICOT/DIETL, "Informations(de-) regulierung am Kapitalmarkt", cit. nota ${ }^{\circ}$ 140, p. 113; FILIPIUK, Transparenz der Risikoberichterstattung, cit. nota $\mathrm{n}^{\circ} 16$, pp. $76-85$.

${ }^{144}$ FILIPIUK, Transparenz der Risikoberichterstattung, cit. nota ${ }^{\circ} 16, \mathrm{p} .94$.

${ }^{145}$ FILIPIUK, Transparenz der Risikoberichterstattung, cit. nota ${ }^{\circ} 16$, p. 86; en la literatura chilena ZARHI, Oscar, "La teoría de los mercados eficientes como garantía de una correcta fiscalización del mercado de valores", en GONZÁLEZ, Marco (Ed.): Regulaciones en el mercado de valores, Cuadernos de Extensión Jurídica $N^{\circ}$ 19, Santiago: Universidad de los Andes, 2010, p. 54. 
Polít. crim. Vol. 8, № 15 (Julio 2013), Art. 2, pp. 23 - 63.

[http://www.politicacriminal.cl/Vol_08/n_15/Vol8N15A2.pdf]

concreto relativo a la dudosa relación de causalidad entre la conducta del iniciado (o insider) y la conducta de su contraparte anónima (víctima), mientras que para el derecho penal, queda pendiente un análisis más profundo del fenómeno de la administrativización del derecho penal y la idealización del mercado de valores como objeto de protección penal $\mathrm{y}$, con ello, el abandono de la literatura penal de la búsqueda de un injusto calificado que justifique la imposición de una sanción penal en este ámbito. 
GARCÍA PALOMINOS, Gonzalo. "Modelo de protección en normas administrativas y penales que regulan el abuso de Información Privilegiada en la legislación chilena".

\section{BIBLIOGRAFÍA}

ALCALDE RODRÍGUEZ, Enrique, "Uso de Información Privilegiada: Algunas consideraciones sobre el sentido y alcance de la prohibición en relación con su sujeto, objeto y sanción", Revista Chilena de Derecho, vol. 27, № 1 (2000).

ASSMANN, Heinz-Dieter, "Das künftige deutsche Insiderrecht (II)", en: Die Aktiengesellschaft (AG), Zeitschr. fu $r$ das gesamte Aktienwesen, fu $r$ deutsches, europa isches und internationales Unternehmens- und Kapitalmarktrecht Vol. 39, 1994.

Kapitalanlagerechts, 3a Ed., 2003.

BAJO FERNÁNDEZ, Miguel; BACIGALUPO, Silvina, Derecho Penal Económico, Madrid: Ramón Areces, 2001.

BAJO FERNÁNDEZ, Miguel, Uso de información privilegiada, en: El nuevo Código penal: presupuestos y fundamentos, Libro Homenaje al Prof. Dr. D. Ángel Torío López, Granada: Comares, 1999.

BASCUÑÁN RODRIGUEZ, Antonio, "La regulación de la información Privilegiada en el mercado de Valores después de la Ley 20.382”, en: VVAA, "Gobiernos Corporativos. Aspectos especiales de las Reformas a su regulación”, Universidad Adolfo Ibáñez, Santiago: Editorial AbeledoPerrot, 2011.

BUCK-HEEB, Petra, Kapitalmarktrecht, "§ 1 II”, Müller, Heidelberg: Editorial C. F. 2008.

CANALES, Patricia, Información Privilegiada en la Ley del Mercado de Valores, Serie Estudios de Anticipación/CEA, Biblioteca del Congreso Nacional de Chile, Año II No. 18, Mayo de 2003.

CASPARI, Karl-Burkhard, "Die geplante Insiderregelung in der Praxis", Zeitschrift für Unternehmens- und Gesellschaftsrecht (ZGR), 1994, pp. 530 - 546.

COLLAO MANSILlA, Patricio (Tesis de Grado), De la Información privilegiada en la Ley de Mercado de Valores, Universidad de Chile, Santiago de Chile, 1998.

DINGELDEY, Thomas, Insider Handel und Strafrecht, München: Editorial Carl Heymanns KG.

DOUKLIAS, Sotirios, Der börsenorientierte Anlageschütz und seine strafrechtliche Absicherung, München: Editorial Herbert Utz, 2007.

FAMA, Eugene, "Efficient Capital Markets: A Review of Theory and Empirical Work", Journal of Finance, Vol. 25, (2), 1970, pp. 383 - 417.

FARALDO CABANA, Patricia, "Algunos aspectos del delito de uso de información reservada en el mercado de valores en el proyecto de Código Penal de 1994", Estudios Penales y Criminológicos, Univ. Santiago de Compostela, XVIII, 1995, pp. $56-58$.

FILIPIUK, Bogna, Transparenz der Risikoberichterstattung, Wiesbaden: Gabler Ed. Wissenschaft, 2008.

GASPAR, José Antonio; ARAYA, Fernando, "Uso de Información Privilegiada: Superintendencia de Valores y Seguros, 14 de abril de 2011, Resolución Exenta N ${ }^{\circ}$ 229”, Revista Chilena de Derecho Privado, No 17 (2011), pp. 277 - 305.

GEHRMANN, Philipp, Das versuchte Insiderdelikt, Baden Baden: Editorial Nomos, 2009. 
Polít. crim. Vol. 8, № 15 (Julio 2013), Art. 2, pp. 23 - 63.

[http://www.politicacriminal.cl/Vol_08/n_15/Vol8N15A2.pdf]

GIESZE, Craig R., "El análisis económico de la Información Privilegiada en el Mercado de Capitales y Valores: ¿Justicia Ineficiente?”, Revista Chilena de Derecho, Vol. 26, № 4, 1999, pp. $799-838$.

GÓMEZ INIESTA, Diego, La utilización abusiva de información privilegiada en el mercado de valores, Madrid: McGraw Hill, 1997.

GRUNEWALD, Barbara, "Neue Regeln zum Insiderrecht", Zeitschrift für Bankrecht und Bankwirtschaft (ZBB), 1990, pp. 128 - 133.

GUZMÁN ANRIQUE, Francisco, Información Privilegiada en el Mercado de Valores, Santiago: Lexis Nexis, 2007.

HADDOCK, David; MACEY, Jonathan, "A Coasian Model of Insider Trading", Northwestern University Law Review, Vol. 80 (1986), pp. 1449 - 1472.

HEISE, Detlef, Der Insiderhandel an der Börse und dessen strafrechtliche Bedeutung, Frankfurt a. M.: Peter Lang Verlag, 2000.

HERNÁNDEZ SAINZ, Esther, El abuso de información privilegiada en los mercados de valores, Pamplona: Thomson Civitas, 2007.

HIENZSCH, André, Das deutsche Insiderhandelsverbot in der Rechtswirklichkeit, Nomos Verlag, 2005.

HOPT, Klaus; WILL, Michael, Europäisches Insiderrecht, Stuttgart: Enka, 1973.

JARA AMIGO, Rony, "Oferta pública y privada de valores en el mercado norteamericano: Una visión comparada", Revista Chilena de Derecho: Vol. 28, № 1 (2001), p. 87 111.

LIEBEL, Hermann, Täter - Opfer - Interaktion bei Kapitalanlagebetrug, Neuwied: Editorial Luchterhand, 2002.

LÓPEZ BARJA DE QUIROGA, Jacobo, "El Insider Trading”, Anuario de Derecho Penal y Ciencias Penales, Tomo XLVI, año MCMXCIII, pp. 1031 - 1060.

LÜCKER, Volker, Der Straftatbestand des Missbrauchs von Insiderinformationen nach dem Wertpapierhandelsgesetz (WpHG), Köln: Carl Heymanns Verlag, 1998.

LUCO, Nicolás, "Protección a los accionistas minoritarios frente a la toma de control de una sociedad anónima abierta", Revista Chilena de Derecho, Vol. 22, № 3 (1995), pp. $417-438$.

MENNICKE, Petra, Sanktionen gegen Insiderhandel, Berlin: Editorial Duncker \& Humblot, 1996.

MERKT, Hanno; ROSSBACH, Oliver, "Zur Einführung: Kapitalmarktrecht", Juristische Schulung, Zeitschrift für Studium und Ausbildung, München, Frankfurt a. M.: C. H. Beck, 2003, pp. $217-224$.

MONROY ANTÓN, Antonio, El Delito de Abuso de Información Privilegiada en el Mercado de Valores, Madrid: Dijusa Verlag, 2006.

MONTENEGRO, Alex (Tesis de grado), Tutela penal de la Información privilegiada en la Ley 18.045 sobre mercado de valores, Memoria para optar al grado de Licenciado en ciencias jurídicas y sociales, Pontificia Universidad Católica de Chile, Valparaíso, Chile, 2004.

NEE, Victor; INGRAM, Paul, "Embeddedness and Beyond: Institutions, Exchange, and Social Structure", The New Institutionalism in Sociology, New York: Brinton, M. C./ Nee, V (Ed.), pp. $19-45$. 
GARCÍA PALOMINOS, Gonzalo. "Modelo de protección en normas administrativas y penales que regulan el abuso de Información Privilegiada en la legislación chilena".

NERLICH, Heirich, Die Tatbestandsmerkmale des Insiderverbots nach dem Wertpapierhandelsgesetz, Osnabrück: Universitätsverlag Rasch, 1999.

NORTH, Douglass, "Institutions", Journal of Economic Perspectives, vol. 5, № 1 (1991), pp. $97-112$.

ONFRAY VIVANCO, Arturo, "Ilícitos contra la información en las transacciones de valores", Revista de Derecho Consejo de Defensa del Estado, № 5 (2001), pp. 73 105.

OTTO, Harro, "Der Missbrauch von Insider-Informationen als abstraktes Gefährdungsdelikt”, en: SCHÜNEMANN, Bernd/ SUÁREZ, Carlos (Ed.), Bausteine des europäischen Wirtschaftsstrafrechts, Madrid-Symposium für Klaus Tiedemann, Köln, Berlin, Bonn, München: Editorial Carl Heymanns, 1994, pp. 447 - 453.

PALMA JARA, Eduardo, (Informe en Derecho del Caso Lan Chile/ Piñera), Adquisición de acciones Lan Airlines S.A., Inversiones Santa Cecilia S.A., Santiago de Chile, 24 de Enero de 2007, en: Actas del Caso Lan Chile/Piñera (Tomo I). (http://www.japonica.cl/Pinera/TomoI.pdf).

PEETZ, Dietmar, Hedge-Fonds und Finanzmarktinstabilität, Universität Kassel.

(https://kobra.bibliothek.uni-kassel.de/handle/urn:nbn:de:hebis:34-2007011916704.).

PETERS, Peter A., Das deutsche Insiderstrafrecht unter Berücksichtigung strafrechtlicher Konsequenzen für Kreditinstitute und prozessualer Durchsetzung, Frankfurt a. M.: Editorial Peter Lang, 1997.

PFEFFER, Francisco, "Concepto de información privilegiada y deberes de conducta de quienes están en posesión de ella, a la luz de la jurisprudencia emanada de la Excma. Corte Suprema“", Revista de Derecho Comercial, Universidad de Chile, Año 1 N$^{\circ} 1$ (2010), pp. 155-181.

PFISTER, Bernhard, "Stand der Insiderdiskussion", Zeitschrift für Unternehmens- und Gesellschaftsrecht (ZGR), Vol. 10 (1981), pp. 338 - 356.

PICOT, Arnold; DIETL, Helmut, "Informations(de-) regulierung am Kapitalmarkt aus institutionenökonomischer Sicht", en: SCHENK, E; SCHMIDTCHEN, D. (Ed.), Jahrbuch für neue politische Ökonomie, Neue politische Ökonomie der Regulierung, Deregulierung und Privatisierung, Vol. 13, Tübingen: Mohr, 1994, pp. 113 - 136.

PIÑA ROCHEFORT, Juan Ignacio, "Algunos problemas del delito de uso de información privilegiada", Cuadernos de Extensión Jurídica, Santiago, tomo 19 (2009), pp. 113 135;

PRADO PUGA, Arturo, “Acerca del concepto de Información Privilegiada en el mercado de valores chileno: Su alcance, contenido y Límites", Revista Chilena de Derecho, vol. $30 \mathrm{~N}^{\circ} 2$ (2003), pp. $237-269$.

RICHTER, Rudolf; FURUBOTN, Eirik, Neue Institutionenökonomik, Tübingen: $3^{\text {a }}$ edición, Editorial Mohr Siebeck, 2003.

RIED UNDURRAGA, José Miguel, "Fundamentos de la Prohibición del Uso de la Información Privilegiada en Chile: Una visión crítica", Revista Chilena de Derecho, vol. 31, No 3 (2004), pp. $439-463$.

"El caso Consorcio 2 - Banco de Chile: Información Privilegiada y Potestad sancionadora de la Administración, en: Sentencias Destacadas 2005 una mirada desde la perspectiva de las políticas públicas, Revista del Instituto Libertad y Desarrollo, Santiago, 2005, pp. 31 - 44. 
Polít. crim. Vol. 8, № 15 (Julio 2013), Art. 2, pp. 23 - 63.

[http://www.politicacriminal.cl/Vol_08/n_15/Vol8N15A2.pdf]

ROJAS, Luis Emilio, "Perjuicio Patrimonial e Imputación Objetiva", Revista de Derecho de la Pontificia Universidad Católica de Valparaíso: Vol. XXXVII, $2^{\circ}$ Semestre de 2011, pp. $417-420$.

ROSAS, Juan Ignacio, “El Delito de Abuso de Información Privilegiada en el Mercado de Valores: Análisis crítico de la regulación contenida en la Ley $\mathrm{N}^{\circ} 18.045 "$, Revista Gaceta Jurídica, № 299 (2005), pp. 7 - 24.

ROSENBLUT, Verónica, "El denominado caso "Schwager": Análisis de histórica condena por uso de información privilegiada y manipulación bursátil", Revista Jurídica del Ministerio Público: N46, marzo 2001, pp. $197-209$.

SALAH ABUSLEME, María Agnes, Responsabilidad por uso de Información Privilegiada en el Mercado de Valores, Santiago: Lexis Nexis, 2004.

SCHRÖDER, Christian, Handbuch Kapitalmarktstrafrecht, Capitulo 2, Köln: Editorial Carl Heymanns, 2007.

SEMINARA, Sergio, "Kapitalmarktinformationen und Strafrecht in rechtsvergleichender Sicht", en: SIEBER, Ulrich (Ed.), Festschrift für Klaus Tiedemann zum 70 Geburtstag, Köln: Carl Heymanns Verlag, 2008, p. 1089 - 1108.

SETHE, Rolf, "§ 12 WpHG Insiderrecht", en: ASSMANN/SCHÜTZE, Handbuch des Kapitalanlagerechts, 3a Ed., 2007.

SOESTERS, Frank, Die Insiderhandelsverbote des Wertpapierhandelsgesetzes, Frankfurt a. M: Editorial Peter Lang, 2002.

STIPP, Anne Caroline, El Delito de Abuso de Información Privilegiada, Bogotá, Colombia: Editorial Leyer, 2009.

STRATENWERTH, Günter, "Zum Straftatbestand des Missbrauchs von Insiderinformationen", en: VV.AA., Festschrift für Frank Vischer, Editorial Schulthess Polygrafischer, Zurich, 1983, p. 667 - 676.

TRUCCO, Eduardo, Las Bolsas de Valores y su Reglamentación, Santiago: Editorial Jurídica Ediar - ConoSur, 1989.

VASQUEZ PALMA, María Fernanda, "Revisión del ámbito de aplicación subjetivo y objetivo de la noción de uso de información privilegiada en Chile: un examen de la normativa a la luz de las tendencias doctrinales y jurisprudenciales", Revista de Derecho Universidad Católica del Norte, Año 17 - N 2 (2010), pp. 239 - 297.

WEBER, Andreas, "Das neue deutsche Insiderrecht", Betriebs-Berater (BB), Vol. 4 (1995), pp. $157-165$.

ZARHI, Oscar, "La teoría de los mercados eficientes como garantía de una correcta fiscalización del mercado de valores”, en: GONZÁLEZ, Marco (Ed.), Regulaciones en el mercado de valores, Cuadernos de Extensión Jurídica $N^{\circ}$ 19, Santiago: Universidad de los Andes, 2010, pp. 54 y ss.

ZIOUVAS, Dimitris, Das neue Kapitalmarktstrafrecht Europäisierung und Legitimation, Köln: Editorial Carl Heymanns, 2005. 